\title{
Review on Spent Nuclear Fuel Performance and Degradation Mechanisms under Long-term Dry Storage
}

\section{사용후핵연료의 장기 건식 건전성 성능과 주요 열화 기구에 관한 고찰}

\author{
Juseong Kim ${ }^{1}$, Donghak Kook ${ }^{1,2}$, Jeehyung $\mathrm{Sim}^{1}$, and Yongsoo Kim ${ }^{1 *}$ \\ ${ }^{1}$ Hanyang University, 222 Wangsimni-Ro, Seongdong-Gu, Seoul, Korea \\ ${ }^{2}$ Korea Atomic Energy Research Institute, 111 Daedeokdae-Ro 989, Yuseong-Gu, Daejeon, Korea \\ 김주성 ${ }^{1}$, 국동학 1,2 , 심지형 ${ }^{1}$, 김용수 ${ }^{*}$ \\ 1 한양대학교, 서울특별시 성동구 왕십리로 222 \\ 2 한국원자력연구원, 대전광역시 유성구 대덕대로 989 번길 111
}

(Received November 25, 2013 / Revised December 6, 2013 / Approved December 9, 2013)

\begin{abstract}
As the capacity of spent nuclear fuel storage pool at reactor sites becomes saturated in ten years, long term dry storage strategy has been recently discussed as an alternative option in Korea. In this study, we reviewed safetycriteria-related research results on spent nuclear fuel performance and integrity under long-term dry storage and proposed the direction and the scope of future domestic research and development. Creep and hydride effect in relation to the embrittlement are known to be the major degradation mechanisms of the spent fuels during the long term dry storage. However, recent research results showed that hydride reorientation and hydride embrittlement are one of the most critical factors to the spent fuel integrity. Accordingly safety criteria of US and Japan for the storage system are basically founded on those mechanisms. However, in Korea, not only in-pile but out-of-pile experimental data have not been generated to understand fuel cladding degradation and to determine the criteria to ensure the safety. In addition, the transient behavior of the spent fuel during transportation also needs to be thoroughly examined. Therefore, various experimental research and development will be required to establish our own safety criteria for future long-term dry storage of domestic spent fuels.
\end{abstract}

Keywords: Dry Storage, Spent Nuclear Fuel, Degradation Mechanism, Safety Criteria

최근 국내에서도 원전 부지 내에 건설 된 습식저장조의 용량이 곧 포화될 것으로 예상되어 사용후핵 연료의 건식저장에 관한 논의가 활발하다. 이 논문에서는 앞으로 다양하게 논의될 저장시스템의 안전성과 함께 장기 건식저장 시 발생하는 사용후핵 연료의 특성 및 건전성 변화에 대해 이제까지 국내외에서 연구 보고된 내용들을 면밀히 검토하고 향후 추구해야 할 연구방 향을 제시하고자 하였다. 조사 결과 건식저장 기간 동안 진행 될 수 있는 여러 피복관 열화기구 중에서 가장 대표적인 기구는 크립 변형과 수소화물에 의한 영향이었으며, 이들이 사용후핵연료 장기 건식저장 시 규제기술기준의 주요 근간을 이루고 있 는 것으로 분석되었다. 한편 과거에는 피복관의 크립 변형이 가장 중요한 열화기구로 평가되었으나, 최근의 연구 결과를 통 해 수소화물에 의한 영향이 더 심각한 것으로 드러났고 이는 미국의 규제기준과 새로운 온도 범위를 제시하고 있는 일본의 규제기준에서 확인할 수 있었다. 그러나, 아직까지 수소화물에 의한 영향이 발생하는 응력과 온도 조건을 명확히 규명할 수 있는 연구 자료가 충분하지 못하며, 나아가 사용후핵연료의 취급 시 거동에 대한 연구도 지속적으로 수행해야 할 부분으로 드러났다. 따라서 국내 사용후핵연료 특성에 맞는 건식저장조건을 수립하기 위해서는 국내에서도 본격적인 연구를 통해 이 들 자료에 대한 충분한 생산과 평가 및 분석이 뒤따라야 할 것으로 판단된다.

중심단어 : 건식저장, 사용후핵연료, 열화기구, 규제요건

*Corresponding Author.

Yongsoo Kim, Hanyang University, E-mail: yongskim@hanyang.ac.kr, Tel: +82.2.2220.0462 


\section{1.서 론}

현재 국내에는 각각 19 기와 4 기의 가압경수로와 중 수로가 가동 중이고 현재 건설 중이거나 건설 예정된 원전 은 총 11 기 이다. 이들 원전에서 방출되는 사용후핵연료 는 최종 처분되기 전 원자로 부지 내의 습식 저장조에서 5 년부터 15 년 정도 임시 보관된다. 이 기간이 끝난 후 사 용후핵연료를 처분하는 방법은 심지층에 영구 처분하거 나, 혹은 재처리 후 발생하는 고준위 폐기물을 영구처분 하는 방식이 있다. 현재 우리나라는 아직 최종 처분 방식 을 결정하지 못하고 국내 경수로에서 발생된 사용후핵연 료 모두를 발전소 내 수중 저장조에서 보관되고 있다. 그 러나 국내 원전의 저장조 용량의 한계로 2025년경에는 이 시설이 포화될 것으로 예상되고 있다. 따라서 사용후핵연 료를 처분하기 위한 그 중간단계로 사용후핵연료를 공기 나 불활성 기체로 채워진 별도의 용기에 저장하는 건식저 장 방법이 현실적인 대안으로 부상하고 있다. 건식저장 방 식의 경우 안전성, 경제성 측면에서 유리한 것으로 평가되 고 있으며 최근에는 대부분의 국가에서 이 방식을 이용하 고 있는 추세이다.

Fig. 1 은 국내 경수로 사용후핵연료 발생량과 연소도 추이를 보여준다[1]. 그림에서 알 수 있듯이 2008년 기준 국내 사용후핵연료의 평균 연소도는 $45 \mathrm{GWd} / \mathrm{tU}$ 에 이르 고 있으며 최대 연소도 또한 $55 \mathrm{GWd} / \mathrm{tU}$ 를 초과한 연료가 방출되었고 2012년 12월 기준[2] 국내 경수로 사용후핵연 료 저장량은 5,744 톤에 이르고 있다.

일반적으로 사용후핵연료는 원자로 부지 내 습식저장

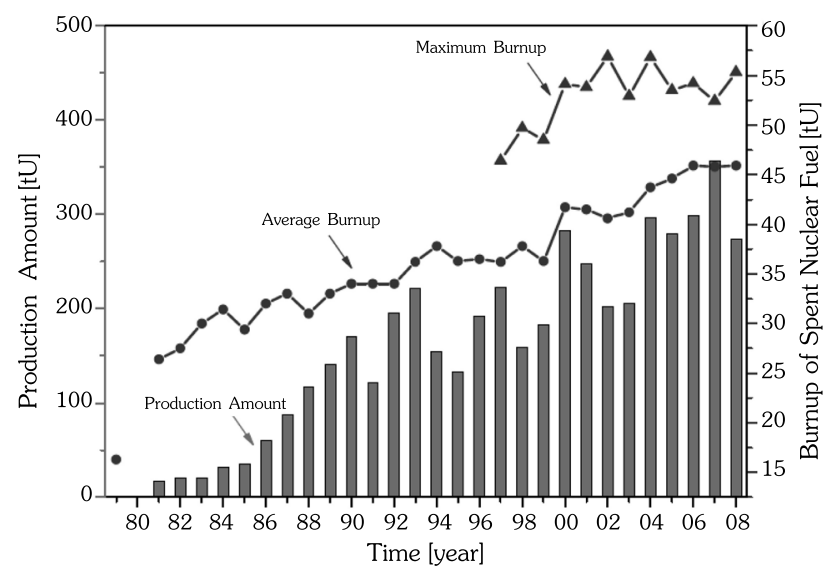

Fig. 1. Annual Production Amount and Burn-up Trend of Domestic Spent Nuclear Fuel[1].
조에서 최소 5 년 이상 저장된다. 사용후핵연료는 습식저 장 이후 건식저장을 위해 저장조로부터 인출되어 진공 건 조 및 헬륨장입 과정을 통하여 피복관 및 집합체 표면에 남아 있는 습기를 제거한 후 건식저장용기에 장입된다. 습 식저장조에서 인출되는 시점이 건식저장의 시작점이라고 할 수 있는데, 이때 사용후핵연료에서 발생하는 잠열에 의 해 사용후핵연료 피복관의 온도는 $400^{\circ} \mathrm{C}$ 이상에[3, 4] 이 르게 된다.

사용후핵연료의 건전성에 영향을 미칠 수 있는 요인 들로는 크립(creep)[5-7]과 수소화물재배열[8-10], 지연수 소화균열(Delayed Hydride Cracking, DHC)[11-13], 응력 부식균열[14, 15], 산화 및 부식에 의한 파괴 등을 들 수 있 다[16]. 미국 원자력안전규제위원회(U.S. Nuclear Regulatory Commission, NRC)는 건식저장 초기에는 여러 열화 기구 중에서 크립을 주요 열화기구로 지목하고 피복관의 온도를 제한하는 방법을 제안하였으나 [17-20] 이후 크립 변형률을 $1 \%$ 내로 제한하였다[21]. 그러나 최근에는 수소 화물재배열, 지연수소화균열, 수소취성 등의 수소화물로 인한 연료의 건전성 저하가 피복관의 건전성을 위협하는 주요 열화기구로 거론되고 있다[22-24]. 따라서 규제 요건 또한 피복관의 원주응력을 $90 \mathrm{MPa}$ 이하로 유지하고 열주 기(thermal cycling) 횟수를 제한하는 등[25, 26] 수소화물 로 인한 연료의 건전성 저하가 발생하지 않는 방향으로 변 화하고 있는 실정이다[27].

위에서 언급된 열화기구들은 원자로 내 연소에 따른 기체상 핵분열생성물에 의한 봉내압과 산화막 두께, 수소 농도 등의 피복관의 재료적인 조건에 의해 직·간접적으 로 영향을 받고 있다. 따라서 이 연구에서는 방출 연소 도에 따른 사용후핵연료의 산화막 두께, 수소농도, 봉내 압 등의 사용후핵연료 피복관 열화에 직·간접적으로 영향 을 미치는 국내 사용후핵연료의 재료적 조건을 조사하였 고 Origen-ARP를 이용하여 연소이력에 따른 사용후핵연 료의 방사능 및 붕괴열에 대해 계산하였다. 또한 건식저장 동안 사용후핵연료 피복관의 주요 열화기구로 작용하고 있는 수소화물재배열, 지연수소화균열 등의 주요 열화기 구를 분석하고 이를 바탕으로 건식저장을 경험한 일부 선 진국의 규제요건을 재료적인 관점에서 기술하였다.

\section{2. 사용후핵연료 피복관의 재료적 특성}

건식저장 조건에서 사용후핵연료 피복관의 연성 감소 


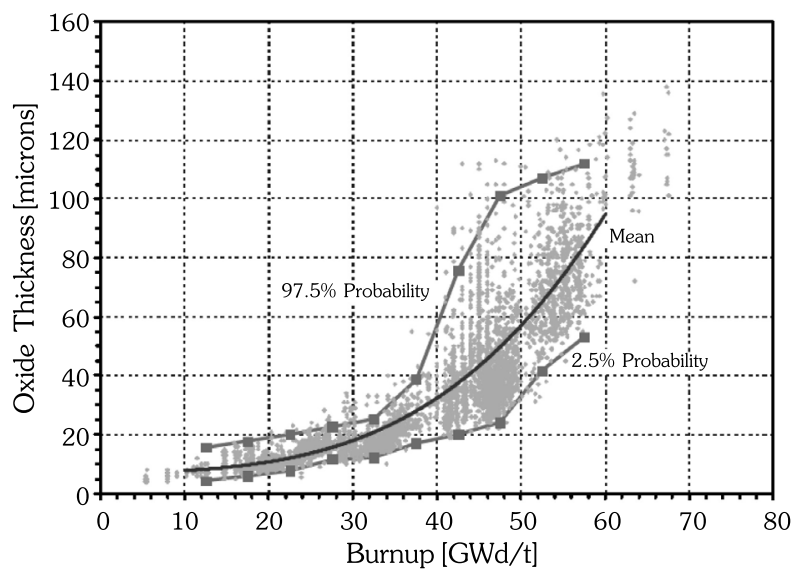

Fig. 2. Cladding Surface Oxide Layer Thickness Distribution as a Function of Average Burn-up[28].

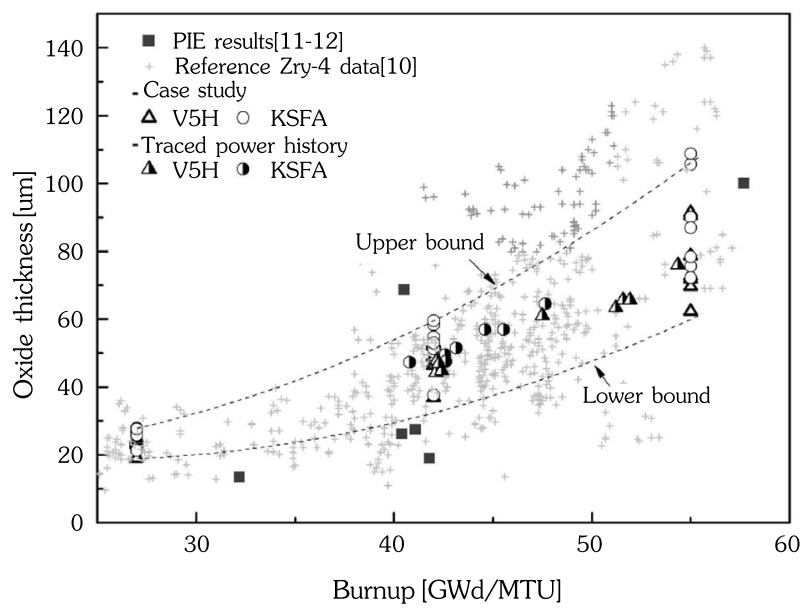

Fig. 3. Effect of Thermal History on Oxide Layer Thickness Distribution of Domestic Spent Nuclear Fuel (SNF) as a Function of Rod Average Burn-up[29].

요인은 크게 수소화물에 의한 것과 중성자 조사에 의한 것 이 있는데 조사에 의한 경화는 상대적으로 높은 피복관의 온도로 인해 어느 정도 완화 될 수 있을 것으로 예상된다. 따라서 이 연구에서는 조사에 의한 영향을 제외한 사용후 핵연료 피복관의 재료적 특성을 보고자 하였다.

\section{1 사용후핵연료 피복관의 산화막과 수소농도}

일반적으로 핵연료의 연소도가 증가할수록 피복관의 산화막 두께와 수소농도는 증가한다. 산화막 두께 증가에
의한 피복관내의 수소농도 증가는 결국 피복관을 취화시 켜 재료적 건전성을 저하시킨다. 지르코늄의 산화는 기본 적으로 다음과 같은 식으로 표현된다.

$$
\mathrm{Zr}+2 \mathrm{H}_{2} \mathrm{O}=\mathrm{ZrO}_{2}+4 \mathrm{H} \text { or } 2 \mathrm{H}_{2}
$$

Fig. 2는 2000년 대 중반 미국전력연구원(Electric Power Research Institute, EPRI)에서 보고한 연료봉 평균 연소 도에 따른 피복관의 최대 산화막 두께를 보여준다[28]. 그 림에서 보는 바와 같이 연소도 $40 \mathrm{GWd} / \mathrm{tU}$ 을 넘어서면서 부터 산화막 두께는 많은 편차를 보이고 있는데 이는 동일 한 연소도에서도 연소이력에 따라 산화막 두께가 달라지 기 때문이다[29].

Fig. 3은 최근 국내에서 보고된 연구결과로 국내 사용 후핵연료 피복관의 산화막 두께에 미치는 연소도의 영향 을 보여준다. 연구결과 산화두께의 평균적인 거동은 EPRI 결과와 매우 유사하지만 동일한 연소도를 가질지라도 산 화막 두께는 연소이력에 영향을 받고 연소도가 증가할수 록 그 영향은 커진다는 것을 알 수 있다. 그림에서 알 수 있 듯이 연소도 $55 \mathrm{GWd} / \mathrm{tU}$ 에서는 $100 \mu \mathrm{m}$ 이상의 산화막이 생성될 수 있으며 연소이력에 따라 약 $40 \mu \mathrm{m}$ 이상의 편차가 생길 수 있다. 고연소 연료에서 산화가속화가 일어나는 원 인으로 수소화물에 의한 영향이 지목되고 있으며[30-32], 산화막 표면에 크러드(CRUD)가 침전되는 경우 크러드의 낮은 열전도도로 인해 금속계면의 온도는 더욱 증가하여 산화막의 두께는 더 증가할 수 있다[33].

피복관의 수소화는 지르코늄과 냉각수의 부식으로 인 한 필연적인 반응 생성물이다. 즉 수소 흡수(pick-up)란 지르코늄 금속의 수소 친화성으로 인해 산화 반응에서 생 성되는 수소의 일부가 지르코늄 기지 내로 빨려 들어가는 현상으로 흡수되는 분율은 지르코늄합금의 종류와 산화온 도, 압력 등의 함수이지만 최종적으로 피복관 내에 축적되 는 총 수소의 양은 산화량에 비례한다. 경수로에서 운전되 는 Zircaloy-4 피복관의 경우 그 분율은 0.15-0.16 의 값을 갖는다고 알려져 있다[34, 35]. 사용후핵연료 피복관의 산 화막측정은 와전류탐상시험(Eddy Current Testing)을 이 용하여 비교적 손쉽게 측정할 수 있지만, 수소분석의 경우 파괴시험을 수행하고 수소분석기를 이용하여야만 함유량 을 측정할 수 있어서 상대적으로 그 자료가 부족한 실정이 다. 따라서 많은 연구결과들은 시뮬레이션을 이용하거나 모델링을 통해 그 자료를 제시하고 있다. Fig. 4 는 EPRI 
Juseong Kim. et al : Review on Spent Nuclear Fuel Performance and Degradation Mechanisms under Long-term Dry Storage

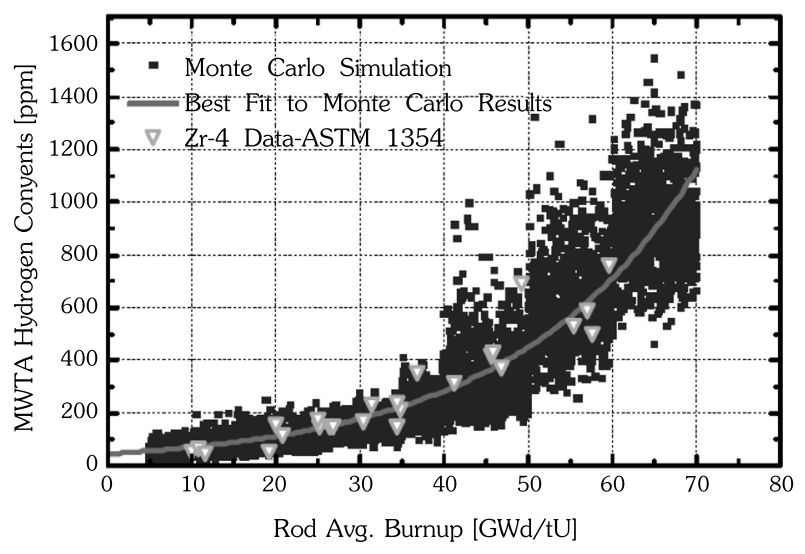

Fig. 4. Hydrogen Content Distribution as a Function of Burn-up in Low-tin Zircaloy-4[28].

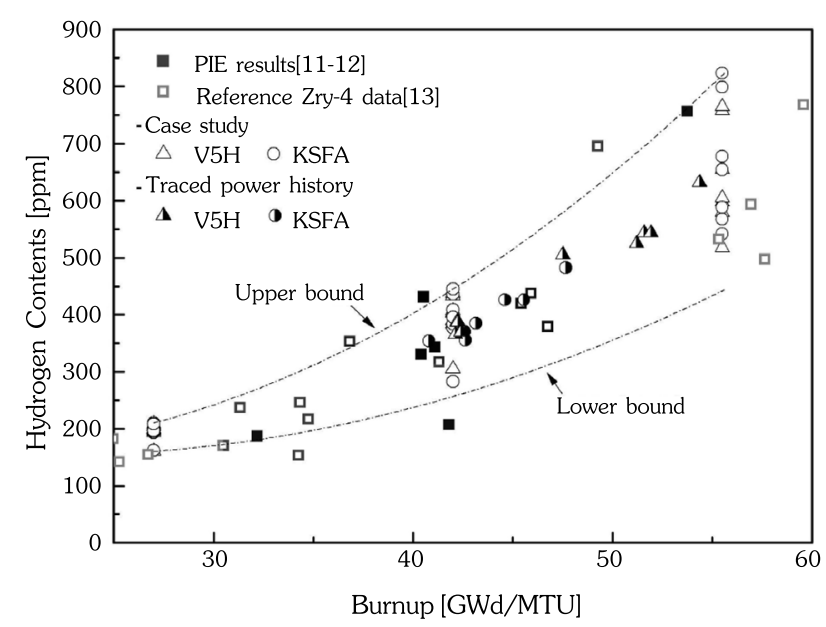

Fig. 5. Effect of Thermal History on Hydrogen Concentration Distribution of Domestic SNF as a Function of Rod Average Burn-up[29].

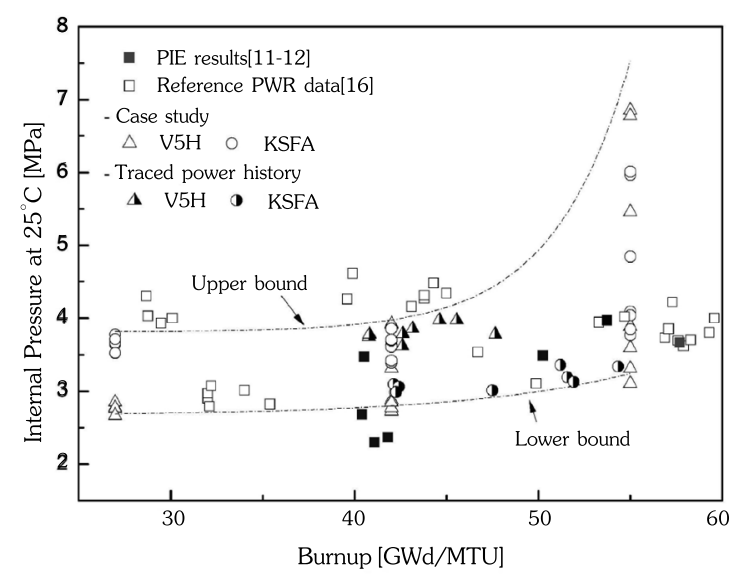

Fig. 6. Internal Rod Pressure Distribution of Domestic SNF at $25^{\circ} \mathrm{C}$ [29].
[28]에서 제시한 연소도에 따른 수소농도 변화를 나타낸 것이다. 그림에서 알 수 있듯이 수소농도는 산화막 두께 에 비례한다는 것을 알 수 있고 연소도 $45 \mathrm{GWd} / \mathrm{tU}$ 이상 에서 $400 \mathrm{wppm}$ 이상의 수소가 피복관 내에 존재할 수 있 다는 것을 보여준다. Fig. 5는 최근 국내 연구결과로 연소 이력이 사용후핵연료 피복관의 수소농도에 미치는 영향을 보여준다. 1990년 후반부터 국내에서 발생된 사용후핵연 료 피복관(Zircaloy-4)의 최대 방출 연소도가 $50 \mathrm{GWd} / \mathrm{tU}$ 를 초과했다는 점을 고려하면 상당수의 국내 사용후핵연 료 피복관도 $600 \mathrm{wppm}$ 이상의 수소를 함유하고 있을 것 으로 예상된다.

\section{2 사용후핵연료의 봉내압}

원자로운전 중 방출된 핵분열생성 기체들에 의한 봉 내압은 장기간의 사용후핵연료 건식저장 기간 동안 피복 관의 크립과 수소화물재배열, 지연수소화균열을 유발하는 직접적 인자로 피복관 열화에 큰 영향을 준다. 사용후핵연 료의 봉내압 또한 산화막 두께나 수소농도와 마찬가지로 연소이력에 따라 핵분열생성 기체의 방출량이 달라진다. 또한 수소분석과 마찬가지로 핫셀시설에서 조사된 핵연료 의 파괴시험을 통해서만 분석이 가능하다. Einziger 등[36] 의 연구결과에 따르면, Surry 원자로에서 방출된 사용후핵 연료의 경우(건식저장용기에 15 년 동안 저장된 사용후핵 연료, 방출연소도: $36 \mathrm{GWd} / \mathrm{tU}$ ) 조사후시험 결과 핵분열생 성 기체의 방출률은 0.5-1\%이었던 반면, Limerick 원자로 사용후핵연료 $(9 \times 9 \mathrm{GE}, 3$-cycle, $56 \mathrm{GWd} / \mathrm{tU})$ 의 경우는 방 출률이 5-17\% 였고, Robinson(15×15 FRA-ANP, 5-7 cycle, $57 \mathrm{GWd} / \mathrm{tU}$ ) 의 경우는 $1.4-2.4 \%$ 이었다[37]. Limerick 사 용후핵연료의 경우 핵연료 소결체 내의 무수한 미세균열 이 높은 방출률의 원인으로 판단되었다. 기본적으로 기체 상 핵분열생성물의 방출률은 연소도가 낮을 때에는 시간 의 제곱근에 비례하지만 연소도가 증가하여 $30 \mathrm{GWd} / \mathrm{tU}$ 를 넘어서게 되면 증가하기 시작하며 $55 \mathrm{GWd} / \mathrm{tU}$ 를 초과 할 경우 급격히 증가할 수 있다고 알려져 있다[38]. Fig. 6 은 국내 사용후핵연료의 연소이력에 따른 봉내압 평가 결 과이다 [29]. 그림에서 알 수 있듯이 연소도가 증가할수록 봉내압은 증가하고 동일한 연소도를 가질지라도 연소이력 에 따라 봉내압의 편차는 커진다. 이는 향후 사용후핵연료 를 구분하는 기준을 선정할 때 연소도 뿐만 아니라 연소이 력 또한 고려해야 한다는 사실을 환기시켜 준다. 


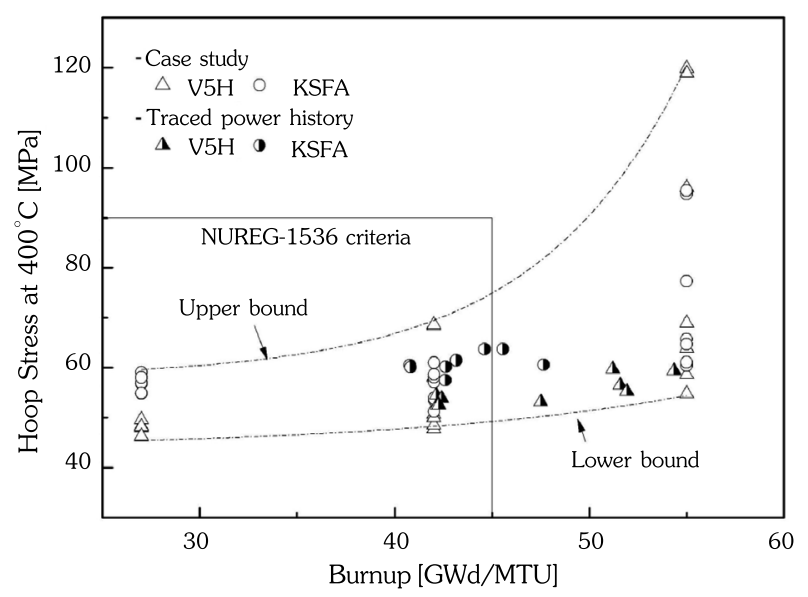

Fig. 7. Cladding Hoop Stress Distribution of Domestic SNF at $400^{\circ} \mathrm{C}$ [29].
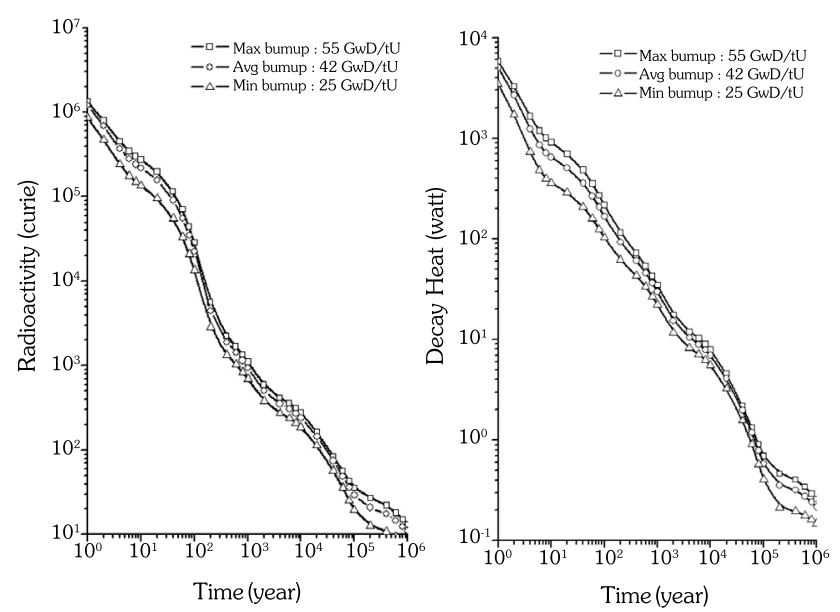

Fig. 8. Radioactivity (left) and Decay Heat (right) of Domestic Spent Nuclear Fuel Assembly.

일반적으로 가연성 흡수체(Burnable Absorber) 연료 봉의 경우 출력이 낮아 산화막 두께, 수소농도, 봉내압 등 이 일반 연료에 비해 상대적으로 낮다고 알려져 있다(국 내에서는 가돌리니아 $\left(\mathrm{Gd}_{2} \mathrm{O}_{3}\right)$ 연료가 주로 사용). 그러나 IFBA (Integral Fuel Burnable Absorber) 연료는 소결체에 보론 $\left(\mathrm{ZrB}_{2}\right)$ 이 코팅되어 있어 헬륨방출로 인해 봉내압이 일반 연료와 비교하여 높은 값을 갖는다[39].

봉내압은 결국 피복관에 원주응력을 형성시키는데 원 주응력은 다음과 같은 관계식으로 환산할 수 있다.

$$
\sigma_{\theta}=\frac{r_{i} P_{i}-r_{0} P_{0}}{t}
$$

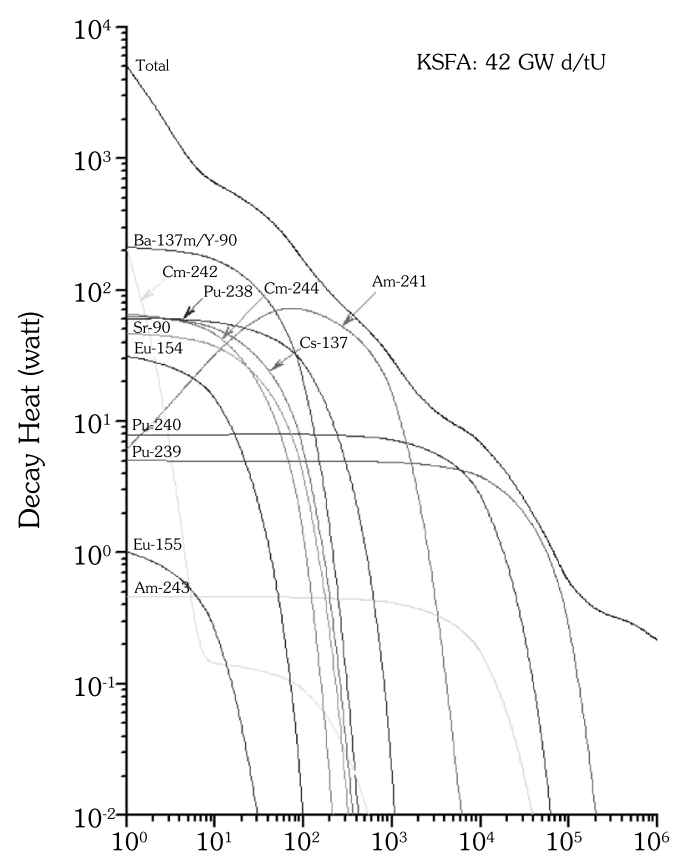

Fig. 9. Variation of Decay heat in Korea Standard Fuel Assembly (42 $\mathrm{GWd} / \mathrm{tU})$.

여기서, $\sigma_{\theta}=$ 원주응력 $(\mathrm{MPa}), r_{i}=$ 피복관 안쪽 반경, $r_{0}$ $=$ 피복관 바깥쪽 반경, $P_{i}=$ 봉내압, $P_{0}=$ 외부기압, $t=$ 산화 막을 제외한 피복관 두께.

Fig. 6 에서 제시된 봉내압은 상온 $\left(25^{\circ} \mathrm{C}\right)$ 에서 제시된 값 으로 건식저장 조건에서 사용후핵연료에 작용하는 원주응 력을 계산하기 위해서는 건식저장 시스템에서 핵연료의 축 방향 온도분포뿐만 아니라 연료의 제원, 열팽창, 연료봉 내부의 핵분열생성기체가 차지하는 공간 등에 대한 계산 이 이루어져야 한다. Fig. 7 은 피복관의 외부 축 방향 온도 를 $400^{\circ} \mathrm{C}$ 로 가정하고 건식저장 조건에서 핵연료에 미치는 응력을 계산한 것이다. 그림에서 알 수 있듯이 $45 \mathrm{GWd} / \mathrm{tU}$ 의 연료의 경우 응력이 $90 \mathrm{MPa}$ 이하였지만 일부 고연소 연 료의 경우 $90 \mathrm{MPa}$ 이상의 응력이 작용할 것으로 예측된다.

\section{3. 사용후핵연료의 방사능 및 열적 특성}

\section{1 방사능과 붕괴열}

국내 사용후핵연료 방출량 추이에 따르면 2020년 경 에는 $16 \times 16$ 표준형 사용후핵연료가 가장 많이 방출될 것 
으로 예상되어[1] 16×16 표준형 사용후핵연료 집합체를 대 상으로 Origen-ARP[40]를 이용하여 사용후핵연료에서 발 생하는 방사능과 붕괴열에 대한 평가 분석을 수행하였다. 또한 연소이력이 붕괴열에 미치는 영향을 판단하기 위해 앞서 조사된 연소이력과 연소도를 [29] 바탕으로 최대연 소도 $(55 \mathrm{GWd} / \mathrm{tU})$, 평균연소도 $(42 \mathrm{GWd} / \mathrm{tU})$, 최소연소도 $(25 \mathrm{GWd} / \mathrm{tU})$ 를 가진 집합체를(초기 농축도 각각 $4.45 \%$, $3.99 \%, 2.37 \%)$ 대상으로 백만년의 시간 변화에 따른 총 방 사능과 붕괴열을 계산하였다. Fig. 8은 시간에 따른 방사 능과 붕괴열변화를 보여준다. Fig. 8 에서 확인할 수 있듯 이 원자로 노외 방출 직후 방사능과 붕괴열의 평균값은 각 각 $\sim 10^{6} \mathrm{Ci}$ 와 $\sim 5000 \mathrm{~W}$ 에 달하지만 시간이 지날수록 지 수적으로 감소하여 100 만 년이 지나면 $\sim 10 \mathrm{Ci}$ 와 $\sim 0.1$ $\mathrm{W}$ 정도로 낮아진다. 평가결과 방사능과 붕괴열은 연소도 차이에 따른 변화는 거의 없는 것으로 드러났다. 위의 계 산 결과를 토대로 건식저장 시 중요하게 평가되는 10 년, 100 년 시점에 방사능과 붕괴열은 초기 대비 각각 $0.1 \%$ 와 $0.01 \%$ 수준으로 감소할 것이라는 것을 예상할 수 있다.

Fig. 9은 국내 사용후핵연료의 붕괴열에 기여하는 주 요 핵종들의 시간에 따른 변화를 나타내고 있다. 붕괴 후
천 년을 전후로 하여 지배적으로 영향을 미치는 핵종에 차 이가 있는 것을 확인할 수 있다. 천년 이전에는 주로 ${ }^{90} \mathrm{Sr}$, ${ }^{90} \mathrm{Y},{ }^{137} \mathrm{Cs},{ }^{137} \mathrm{mBa}$ 과 같은 단반감기 · 고발열성핵종과 ${ }^{238} \mathrm{Pu}$, ${ }^{241} \mathrm{Am},{ }^{242} \mathrm{Cm},{ }^{244} \mathrm{Cm}$ 등 일부 악티나이드 계열의 핵종의 양 이 지배적이며 특히, ${ }^{241} \mathrm{Am}$ 의 경우 붕괴열이 크지 않은 다 른 초우라늄 핵종으로부터 꾸준히 생성되어 붕괴열에 대 한 기여도가 점점 증가함을 확인할 수 있다. 그러나 단반감 기·고발열성핵종이 모두 소멸되는 천 년 이후에는 ${ }^{239} \mathrm{Pu}$, ${ }^{240} \mathrm{Pu},{ }^{243} \mathrm{Am}$ 등 악티나이드 계열의 핵종들에서 주로 붕괴 열이 발생한다. 그러나 그 발생량이 수 와트 이하로 피복관 온도 상승에 미치는 영향은 매우 미미할 것으로 예상된다.

Fig. 10은 국내 표준형 핵연료의 $(55 \mathrm{GWd} / \mathrm{tU})$ 연소이 력에 따른 붕괴열의 변화를 나타내고 있다. 산화막 두께와 수소농도, 봉내압은 연소이력에 큰 영향을 받았지만, 그림 에서 알 수 있듯이 붕괴열은 연소이력에 큰 영향을 받지 않 는다. 저장 초기에는 작은 차이를 갖지만 냉각 10 년 이후 에는 모든 경우에서 동일하였다. 이는 방출 후 약 10 년까 지는 주로 단반감기·고발열성핵종들로부터 붕괴열이 발 생되기 때문이다. 따라서 초기 10 년은 습식저장에 해당되 므로 붕괴열 계산에 있어서 연소이력은 고려하지 않아도
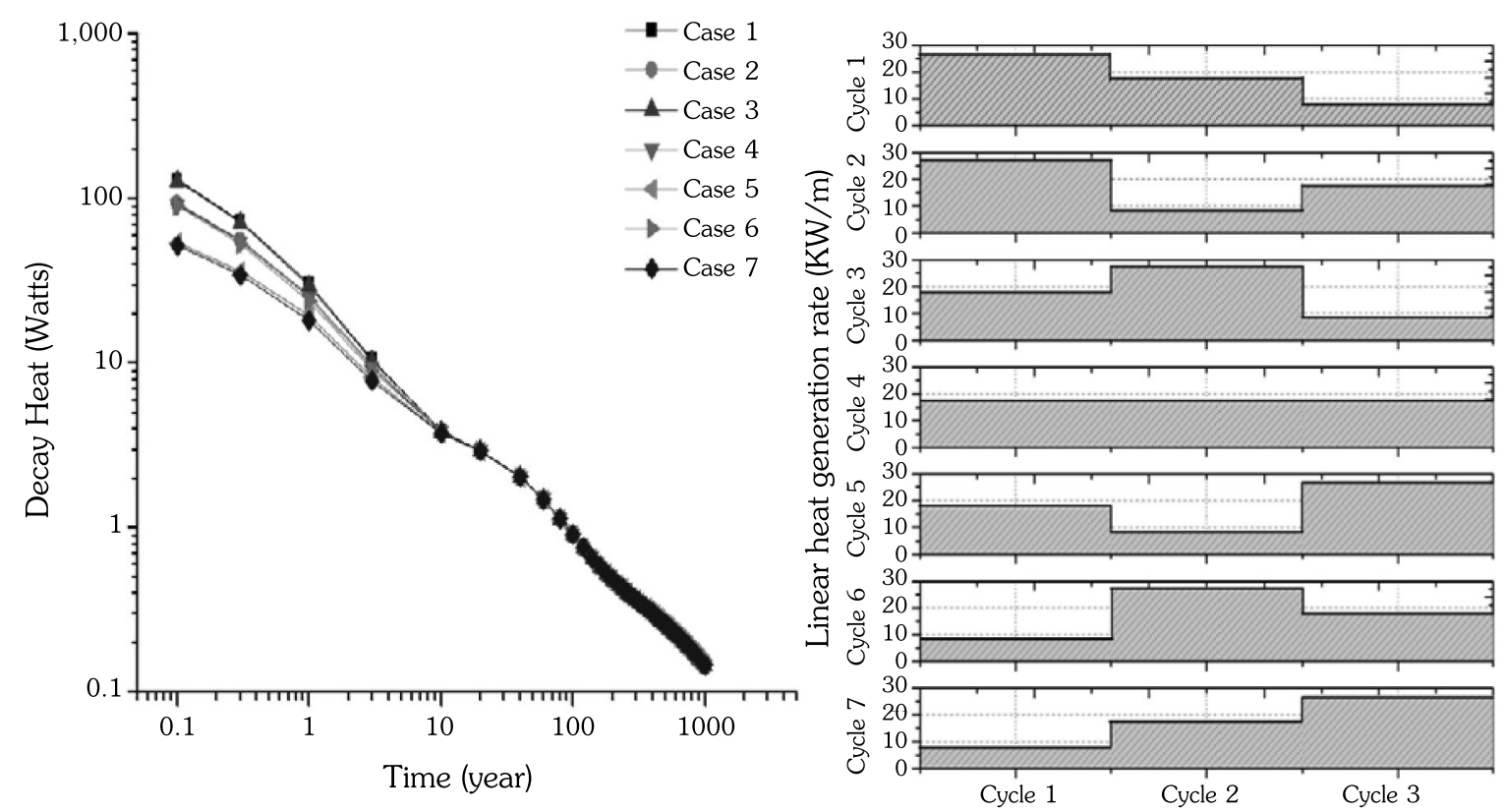

Fig. 10. Decay heat of Korea Standard Fuel Assembly (55 GWd/tU) as a Function of Time (left) and Its Thermal History Used in Calculation (right). 
Juseong Kim. et al : Review on Spent Nuclear Fuel Performance and Degradation Mechanisms under Long-term

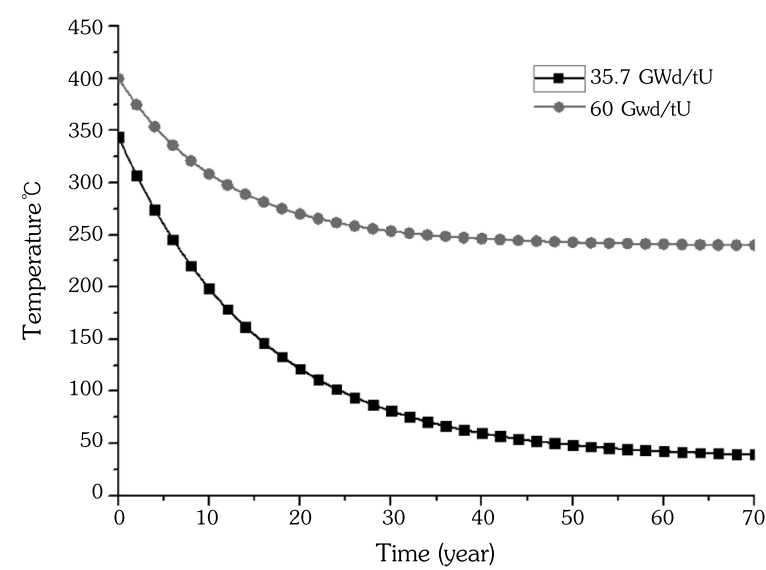

Fig. 11. Cladding Temperature Variation during Dry Storage.

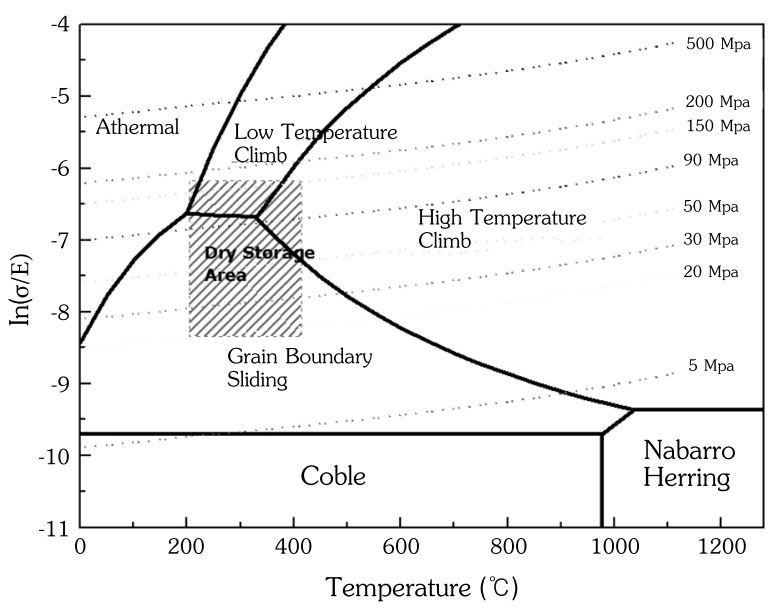

Fig. 12. Zirconium Creep Deformation Map.

될 것으로 판단된다.

\section{2 건식저장 중 사용후핵연료 피복관의 온도}

사용후핵연료를 건식저장 용기에 이송하기 위해 습식 저장조에서 인출하는 순간 붕괴열에 의해 피복관의 온도 는 상승한다. 또한 피복관 외부의 수분을 제거하기 위해 진공 건조를 진행하는 동안 피복관의 온도는 앞서 언급하 였듯이 $400^{\circ} \mathrm{C}$ 이상에 [3, 4] 이르게 된다. 그러나 실제 진 공 건조 과정 중에 핵연료의 온도가 얼마나 상승할 수 있 는지는 진공 건조 시간에 달려있고 이 부분에 대한 추가
적인 연구가 필요한 실정이다. 아래 수식은 미국 전력연 구원(Electric Power Research Institute, EPRI)[41]이 제시 한 건식저장 기간 동안의 피복관의 온도이력 변화를 나타 낸 식이다.

$T=517.48+155.52 \exp (-0.0877 t)-0.06922575 t$

여기서 $\mathrm{T}$ 는 절대온도[K], t는 저장시간[year] 이다. 이 온도분포는 저장용기 바깥의 외부 온도는 $40^{\circ} \mathrm{C}$ 로 고정하 고 공기의 열전달계수를 상수로 가정한 다음 FALCON코 드를 이용하여 시간에 따른 피복관의 온도변화를 구한 식 이다. 또한 초기 저장온도를 $400^{\circ} \mathrm{C}$ 로 가정하였고 연소도 $60 \mathrm{GWd} / \mathrm{tU}$ 의 사용후핵연료가 8.5 년 동안 습식 냉각된 후의 붕괴열을 기반으로 하였다. 한편 실제 핵연료를 운반 용기에 저장하고 15 년 후에 인출하여 실험한 Surry 연료 의 경우 아래의 온도 변화 곡선을 제시하였다[42].

위 온도변화는 초기 저장온도인 $344^{\circ} \mathrm{C}$ 와 14.8 년 후 측

$$
\mathrm{T}=308 \exp (-0.064 \mathrm{t})+309
$$

정결과인 $155^{\circ} \mathrm{C}$ 를 고정하고 대기 중 온도를 가장 더운 여 름의 온도 $\left(38^{\circ} \mathrm{C}\right)$ 로 가정하여 도출되었지만 측정 당시 저 장용기의 뚜껑을 열고 측정하였기 때문에 저장용기 내의 열이 측정값이 실제 값보다 낮을 것으로 예측된다. Fig. 11 은 위의 두 온도 분포를 비교한 것이다. 연소도 $60 \mathrm{GWd} /$ $\mathrm{tU}$ 로 계산된 연료의 경우에는 건식저장 40 년 이후의 온 도가 약 $245^{\circ} \mathrm{C}$ 지만 연소도 $35.7 \mathrm{GWd} / \mathrm{tU}$ 의 Surry 연료의 경우 약 $60^{\circ} \mathrm{C}$ 이다. 이러한 온도 분포에 영향을 미치는 요 인은 앞서 언급된 연소도에 따른 붕괴열, 냉각기간에 따른 연료의 특성과 저장용기의 냉각 성능에 따라 결정된다. 저 장용기 내부는 다양한 재질을 가진 연료바스켓, 차폐체, 캐 니스터 등으로 이루어져 사용후핵연료의 잠열은 다소 복 잡한 열전달 과정을 거쳐 냉각된다. 현재 건식저장 시스템 은 COBRA-SFS[43]와 유한요소해석 프로그램인 PHOENICS-3.2[44], STAR-CCM+[45], FLUENT[46, 47] 등을 이용 하여 온도를 해석하고 있지만 대부분 집합체 자체를 하나 의 열원으로 가정하여 해석한다. 최근 피복관의 온도를 해 석하기 위해 개개의 연료봉에 대한 해석을 수행하고 있지 만 아직 미비한 실정이다[48, 49]. 


\section{4. 사용후핵연료 피복관 열화기구}

앞서 언급하였듯이, 건식저장 기간 중 사용후핵연료 피복관의 물성을 저하시키는 열화기구는 크립, 수소화물 재배열, 지연수소화균열, 응력부식균열, 산화 및 부식 등 이 있지만 본 연구에서는 가장 주요한 열화기구인 크립 과 수소화물에 의한 열화기구에만 초점을 맞추고자 한다.

\section{1 사용후핵연료 피복관 크립}

장기간 동안 고온에 노출되는 사용후핵연료 건식저장 조건에서는 연료봉 내부에 축적된 핵분열생성기체로 인 한 내부 압력에 의해 피복관의 크립 변형이 발생하고 응력 이 높은 경우 크립에 의한 파단(rupture)이 발생할 수 있다. 지르코늄합금 피복관에 작용하는 주요 크립 기구는 지르 코늄의 크립 지도[20]에서 알 수 있듯이 응력과 온도에 따 라 다르다(Fig. 12). 그러나 작용할 수 있는 크립 기구 중 실제 사용후핵연료의 피복관 환경조건에서 작용할 것으 로 예측되는 기구는 전위 상승과 활주(dislocation climb and glide), 결정입계 미끄러짐(grain boundary sliding) 과 Coble 정도이다.

사용후핵연료 피복관의 경우 중성자 조사와 수소화물 의 영향으로 조사되지 않은 핵연료보다 크립 변형량이 작 은 것으로 알려져 있다[50]. Einziger 등[51]은 연소도 27-31 $\mathrm{GWd} / \mathrm{tU}$ 의 사용후핵연료 피복관을 대상으로 $482-571^{\circ} \mathrm{C}$ 의 온도에서 7,600 시간 동안 실험하였는데, 실험 결과 크 립 변형률은 $1.7-7 \%$ 이었으며 피복관에 심각한 균열이 발 견되지 않았다고 보고하였다. 이 결과를 바탕으로 Peehs 등[18]은 피복관의 첨두 온도가 $400^{\circ} \mathrm{C}$ 이하일 경우 전체적 인 피복관의 변형률이 $2-3 \%$ 를 넘지 않는다면 크립은 피 복관의 건전성에 큰 영향을 미치지 않는다고 주장하였다. Spilker 등[52]은 80-150 MPa, 250- $400^{\circ} \mathrm{C}$ 에서 시험을 수행 하였고 크립 변형률 $1 \%$ 이내로 건전성을 유지할 수 있다는 결론을 내렸다. 또한 Ito 등[53]은 피복관에 변형경화법칙 (strain hardening rule)을 적용할 수 있다고 주장하며 정상 상태 크립에서 제 3 차 크립으로 전환되는 변형률로 $1 \%$ 변 형률을 제시하였다. 또한 Goll 등[7]은 연소도 54-64 GWd/ $\mathrm{tU}$, Zircaloy- 4 를 이용해 $300^{\circ} \mathrm{C}$ 와 $370^{\circ} \mathrm{C}, 320-630 \mathrm{MPa}$ 응 력 조건에서 크립 실험을 수행하였는데, $2 \%$ 이내의 균일 소성 변형률 이하에서는 파손이 발생하지 않았다. 이러한
결과를 근거로 EPRI[54]는 $2 \%$ 크립 제한 변형률을 제시한 바 있고 $67 \mathrm{GWd} / \mathrm{tU}$, Zircaloy-4의 크립 변형률이 5\% 이상 에서도 파단이 발생되지 않았다고 보고된바 있다[5]. 실제 건식저장 조건에서 크립은 발생하지만 피복관에 적용되 는 온도와 응력이 낮고 시간이 지날수록 온도와 응력이 감 소하는 건식저장의 특성으로 인하여 현재는 건전성에 심 각한 위협을 주는 열화기구는 아닌 것으로 판단되고 있다.

\section{2 수소화물에 의한 피복관 열화}

\subsection{1 수소화물재배열}

지르코늄합금 수소화물의 배열 방향은 결정방위(texture)와 응력에 영향을 받는다. 따라서 피복관 제조 시 필 거링(Pilgering) 과정을 통해 원주방향으로 수소화물이 생 성되도록 $\mathrm{F}_{\mathrm{n}}$ 지수(전체 수소화물에 대한 반경 방향 수소화 물의 비)를 0.3 이하로 제한하고 있다. 그러나 피복관의 온 도가 상승하게 되면 석출된 지르코늄 수소화물은 용해되 고 이후 서서히 온도가 낮아지게 되면 재침전(re-precipitation)된다. 원주방향의 수소화물이 재침전될 때 높은 응 력에 의해 반경 방향의 수소화물로 배열되는 현상을 수소 화물재배열(Hydride reorientation)이라 한다. Fig. 13은 원주방향의 수소화물과 반경방향의 수소화물을 보여준다 [5]. 수소화물재배열이 문제가 되는 것은 반경 방향의 수 소화물이 피복관내에 존재하는 경우 그 연성이 심각하게 감소하기 때문이다[10, 55-58]. 건식저장 기간 중에는 외 부응력이 존재하지 않으므로 재배열이 발생하더라도 재 료의 손상이 발생하지 않지만 수송 중 갑작스런 충격이 나 외부응력이 존재하는 경우에는 피복관이 심각하게 훼 손될 수 있다.

수소화물재배열은 온도, 응력, 수소화물의 농도, 냉
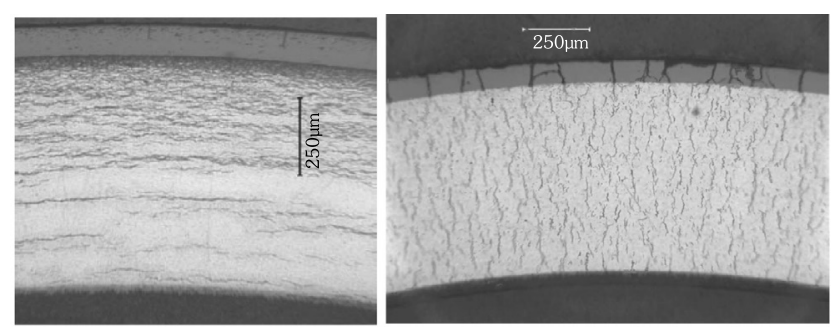

Fig. 13. Hydride Morphology in Irradiated Cladding: Circumferential Hydride (left), and Radial Hydride (right)[5]. 
Juseong Kim. et al : Review on Spent Nuclear Fuel Performance and Degradation Mechanisms under Long-term

Dry Storage

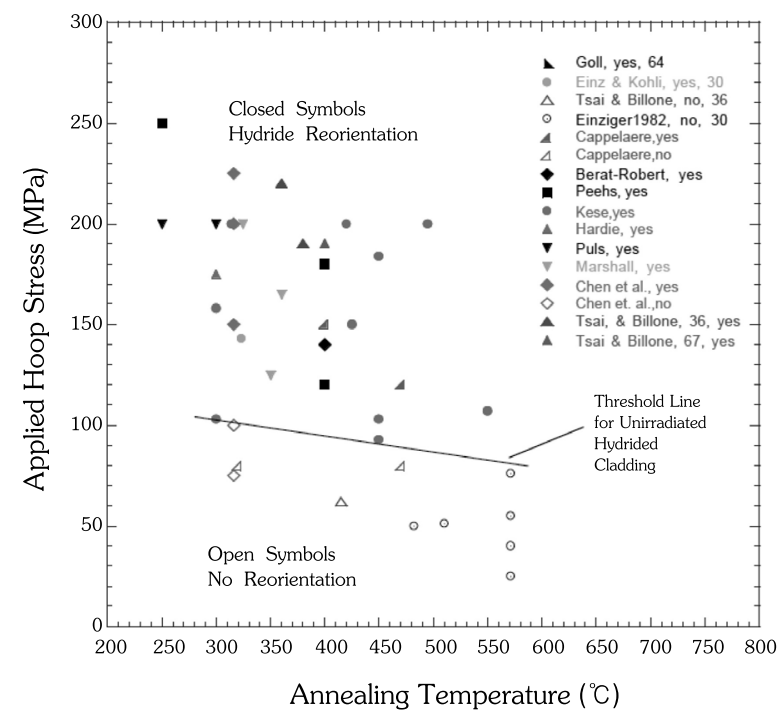

Fig. 14. Threshold Stress for Hydride Reorientation as a Function of Temperature[60].

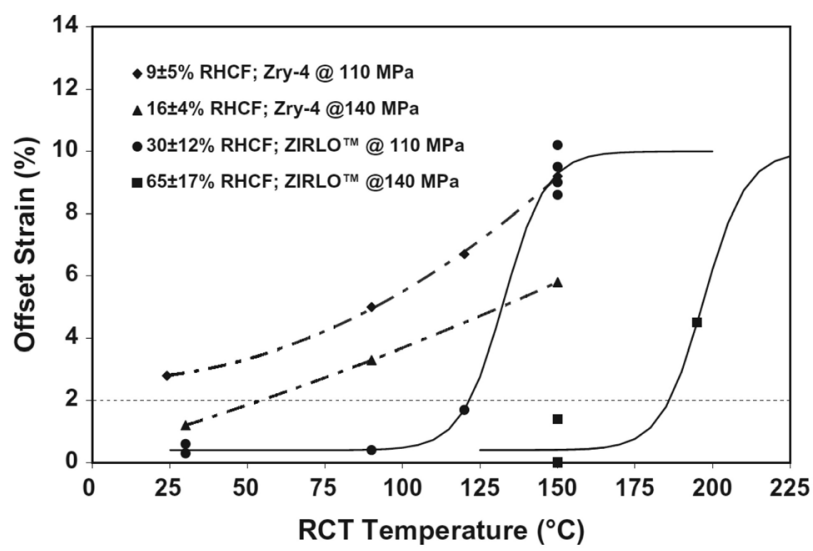

Fig. 15. Offset Strain as a Function of Temperature for High Burn-up Zirlo and Zircaloy-4[57].

각속도, 열주기 횟수 등의 함수로 알려져 있다. 이 중에 서도 수소화물재배열을 발생시키는 문턱응력(Threshold stress)이 가장 중요하다. Kese [59]는 미조사 피복관 인 장실험을 통해 문턱응력이 $90 \mathrm{MPa}$ 이라고 결론 내렸고 Chung [60]은 다른 연구자들의 실험 결과를 종합하여 건 식저장 조건에서 재배열이 나타날 수 있는 문턱응력 값을 90-100 MPa로 주장하였다(Fig. 14). 현재는 이 주장이 받 아들여져 수소화물재배열과 관련된 $90 \mathrm{MPa}$ 의 응력이 규 제요건으로 사용되고 있다[26]. 그러나 최근 연구된 결과 에 따르면 $90 \mathrm{MPa}$ 이하의 응력에서도 수소화물재배열 현
상이 발생할 수 있는 것으로 보고되었다[61, 62]. Daum 등[62]은 조사되지 않은 Zircaloy-4와 조사된 피복관의 문 턱응력은 $400^{\circ} \mathrm{C}$ 에서 각각 $80 \pm 10 \mathrm{MPa}, 75 \pm 12 \mathrm{MPa}$ 이라 고 주장하였다. 그러나 이 문턱응력 또한 피복관의 온도 에 따라 변화한다고 보고되고 있다[55]. Goll 등[7]은 조 사된 Zircaloy-4를 대상으로 $300^{\circ} \mathrm{C}, 100 \mathrm{MPa}$ 의 응력으로 실험한 결과 원주방향의 수소화물이 반경 방향 수소화물 로 변경되는 것을 확인하였고 Oohama등[63] 또한 $300^{\circ} \mathrm{C}$ 에서 $100 \mathrm{MPa}$ 을 문턱응력 값으로 제시하였다. 국내에는 Zircaloy-2 가 사용되지 않았지만 Zircaloy-2의 문턱응력 은 Zircaloy-4와 비슷하거나 더 낮은 값을 갖고[10, 64, 65] Zirlo와 같은 신합금 피복관 같은 경우는 그 자료가 부족 한 실정이다.

수소화물재배열은 일반적으로 열주기 횟수가 증가할 수록 증가한다고 알려져 있지만[9, 66] 명확한 모델은 제 시되지 않은 상황이다. 현재 NRC는 열주기 동안 온도 변 화를 $65^{\circ} \mathrm{C}$ 이내로 제한하고 있는데 제시된 $65^{\circ} \mathrm{C}$ 는 지르코 늄합금 내 수소의 고용도 이력 현상과[67-70] 관계된 값으 로 Kammenzind 등[35, 71]의 결과를 바탕으로 열주기가 $65^{\circ} \mathrm{C}$ 이내인 경우 수소화물재배열이 발생하지 않을 것으 로 판단하였다.

\subsection{2 지연수소화균열}

지연수소화균열(DHC)은 장기간 저장해 둔 $\mathrm{Zr}-2.5 \mathrm{Nb}$ 의 봉단마개 접합부에서 발생한 균열을 통해 발견하였으 며[72], 그 후 실제 운전 중인 중수로 원자력발전소의 압력 관(pressure tube)에서 발견되었다[73]. 이 후 많은 연구자 들에 의해 $\mathrm{DHC}$ 에 대한 연구가 진행되었으며 경수로 사용 후핵연료 피복관에서는 아직 DHC가 발견되지 않았지만 건식저장 조건에서 발생할 수 있는 주요 열화기구로 거론 되고 있다. 건식저장 조건에서 $\mathrm{DHC}$ 는 장기적인 온도 감소 에 따른 수소화물의 석출량 증가와 봉내압에 의해 발생된 다. 이에 영향을 미치는 인자로는 응력, 온도, 냉각방식 그 리고 수소화물재배열인 것으로 평가되고 있으며, 특히 수 소화물의 크기, 방향과 응력의 관계는 DHC의 진행 및 속 도에 큰 영향을 미치는 것으로 알려져 있다. $\mathrm{DHC}$ 는 피복 관 내부 균열이 존재하는 경우 균열선단에서 수소화물이 집중되면서 수소화물로 인한 균열성장에 의해 결국은 파 단에 이르게 되는 현상이다. $\mathrm{DHC}$ 는 온도에 직접적인 영향 을 받는다. $180^{\circ} \mathrm{C}$ 이하에서는 가열 및 냉각에 무관하게 균 열성장이 발생하는 반면 $180^{\circ} \mathrm{C}$ 이상의 온도에서는 냉각시 


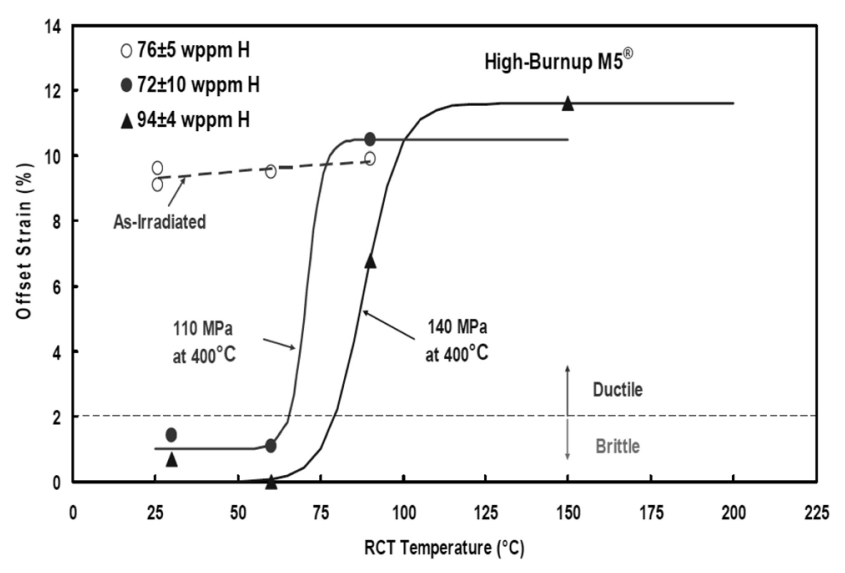

Fig. 16. Offset Strain as a Function of Temperature for High Burn-up M5[83].

에만 균열성장이 발생하고 $300^{\circ} \mathrm{C}$ 이상의 고온에서는 균열 성장이 느려진다[74]. 이는 수소화물의 연성-취성 천이 온 도와 수소고용도의 이력 현상[67]과 밀접한 관련이 있다. 앞선 연구자들에 의해 제안된 DHC의 대표적인 모델로는 균열의 진행 메커니즘에 따라 DFM (Diffusion First Model)과 PFM (Precipitation First Model)이 있다. DFM[11, $13,75,76]$ 은 응력 구배에 의해 수소고용도가 영향을 받아 수소가 벌크로부터 균열선단으로 확산하여 DHC가 발생 하는 이론이고 PFM[12, 77, 78]은 균열 선단에서의 냉각수 소고용도가 낮아져서 수소화물 석출로 인해 DHC 가 발생 하는 이론이다. 그러나 대부분의 DHC연구는 $\mathrm{Zr}-2.5 \mathrm{Nb}$ 합 금에 의해 국한되어 있어서 Zircaloy- 4 나 Zirlo와 같은 재 료에 대한 연구가 필요한 실정이다.

\subsection{3 연성-취성 천이}

일반적으로 수소는 재료에 취성을 유발한다고 알려져 있다. 수소를 함유한 지르코늄합금의 경우 고온에서는 연 성을 유지하지만 온도가 감소하면 연성은 확연하게 감소 하고 취성 파괴된다. 이러한 현상을 연성-취성 천이(Ductile-Brittle Transition, DBT)라고 하고 천이가 발생하는 온 도를 연성-취성 천이 온도(DBTT)라고 한다[57]. 온도가 증 가함에 따라 수소화된 피복관의 연성이 증가하는 이유는 수소화물의 연성이 증가하거나 혹은 지르코늄합금 기지의 연성이 증가하기 때문인데 지르코늄합금 내에 수소화물이 존재할 때 수소화물은 소성 변형이 가능하다는 주장이 제 기되었으나 $[79,80]$ 순수 수소화물은 $600^{\circ} \mathrm{C}$ 의 고온에서도 취성파괴를 일으킨다는 연구결과를 바탕으로 연성의 증가
는 지르코늄 기지의 연성증가로 인한 것이라는 주장이 지 배적이다[81, 82]. DBTT가 중요한 이유는 재료의 연성·취 성 여부를 판단하는 기준이 되기 때문이다. 앞서 건식저장 중 온도 분포(Fig. 11)에서 알 수 있듯이 약 40 년 건식저장 후에 $60 \mathrm{GWd} / \mathrm{tU}$ 사용후핵 연료 피복관의 온도는 약 $250^{\circ} \mathrm{C}$ 이고 $35.7 \mathrm{GWd} / \mathrm{tU}$ 사용후핵 연료 피복관의 온도는 약 $60^{\circ} \mathrm{C}$ 이다. 사용후연료 피복관의 $\mathrm{DBTT}$ 가 $100^{\circ} \mathrm{C}$ 라고 가정하였 을 경우, 두 핵연료 피복관에 충격이 가해진다면 $60 \mathrm{GWd}$ $\mathrm{tU}$ 연료의 경우는 연성을 가지고 있어 충격을 흡수할 수 있지만 $35.7 \mathrm{GWd} / \mathrm{tU}$ 연료는 저연소 연료임에도 충격을 흡수하지 못하고 취성파괴될 것이다. 즉 DBTT는 사용후 핵연료 운반 시기를 결정할 수 있는 중요한 인자이다.

DBTT는 수소화물의 농도와 수소화물의 배열 그리고 재료의 함수이다. 최근 미국 $[57,83]$ 에서는 고연소도 사용 후핵연료가 수송조건에서 발생할 수 있는 기계적 충격에 의한 피복관 손상을 판단하기 위해 피복관 압축실험을 진 행하였다. 대상 피복관은 Zircaloy-4, Zirlo, M5 등으로 수 소화물재배열을 발생시킨 다음 상온에서 $200^{\circ} \mathrm{C}$ 까지 압 축실험을 실행하였는데, 이 실험에서는 반경 방향 재배열 을 유발하는 원주 방향 응력을 변수로 반경 방향 수소화물 연결 인자(Radial Hydride Continuity Factor, RHCF)를 모 델링하고 RHCF 에 따른 피복관의 연성, 취성 여부를 판단 하기 위한 방법론이 개발 중이다. Fig. 15 [57]는 실험온도 에 따른 조사된 지르코늄합금 피복관의 변형률을 보여준 다. 이 그림에서 알 수 있듯이 RHCF가 높은 Zirlo의 경우 DBTT가 $100-200^{\circ} \mathrm{C}$ 사이에 있어 상온에서 취성파단이 발 생했지만 RHCF가 상대적으로 낮은 Zircaloy-4는 상온에서 도 어느 정도 연성을 유지하는 것으로 판단된다. Fig. 16 [83]은 조사된 M5의 압축실험 결과이다. $60 \mathrm{GWd} / \mathrm{tU}$ 이상 의 고연소도에도 불구하고 M5의 수소 농도는 $100 \mathrm{wppm}$ 이하였고 원주응력 $110 \mathrm{MPa}$ 이 작용하였을 때 대부분의 수소화물이 반경 방향으로 재배열되었지만 같은 조건의 Zirlo 에 비하여 DBTT 가 낮았다. 이상의 실험결과에서 알 수 있듯이, DBTT 는 수소화물의 반경방향 배열과 수소 농도에 심각한 영향을 받는다. 그러나 Billone 등 [57, 83] 은 실험적인 결과를 바탕으로 연성·취성 여부를 판단하는 기준으로 $2 \%$ 변형률을 제시하였지만 링 압축시험의 특성 [84, 85]을 고려할 때 $2 \%$ 변형률은 탄성영역을 살짝 벗어 난 보수적인 값으로 논란의 여지가 있다고 판단된다. 또한 $\mathrm{RHCF}$ 를 이용하여 모델링 하였지만 수소화물 재배열 정 도를 나타내는 인자는, 효과적인 수소화물재배열인자(Ef- 
Table 1. Spent Fuel Integrity Criteria for Interim Dry Storage in Japan [27]

\begin{tabular}{|c|c|c|c|}
\hline & \multirow{2}{*}{ Cladding Type } & \multicolumn{2}{|c|}{ Threshold of No Ductility Degradation Affected by Hydride Reorientation } \\
\hline & & Temperature $\left({ }^{\circ} \mathrm{C}\right)$ & Hoop Stress (MPa) \\
\hline \multirow{3}{*}{$\begin{array}{c}\text { BWR Zry-2 } \\
(\mathrm{RX})\end{array}$} & $40 \mathrm{GWd} / \mathrm{tU}$ No Liner & $\leq 200$ & $\leq 70$ \\
\hline & $50 \mathrm{GWd} / \mathrm{tU}$ with Liner & $\leq 300$ & $\leq 70$ \\
\hline & $55 \mathrm{GWd} / \mathrm{tU}$ with Liner & $\leq 300$ & $\leq 70$ \\
\hline \multirow{4}{*}{$\begin{array}{l}\text { PWR } \\
(\mathrm{SR})\end{array}$} & $39 \mathrm{GWd} / \mathrm{tU}$ Zry-4 & $\leq 275$ & $\leq 100$ \\
\hline & $48 \mathrm{GWd} / \mathrm{tU}$ Zry-4 & $\leq 275$ & $\leq 100$ \\
\hline & $55 \mathrm{GWd} / \mathrm{tU}$ MDA & $\leq 250$ & $\leq 90$ \\
\hline & $55 \mathrm{GWd} / \mathrm{tU}$ ZIRLO & $\leq 250$ & $\leq 90$ \\
\hline
\end{tabular}

fective hydride reorientation factor) [10, 63], 수소화물연 결인자(hydride continuity coefficient) [86, 87], 수소화물 재배열비율(hydride reorientation fraction)[88], 반경 방향 수소화물비율(radial hydride fraction) [89]등 여러 가지 인 자가 존재하고 피복관의 연성을 정의하는데 어떤 인자가 효과적인 것인 가에 대한 평가는 아직 알 수 없다. 그러나 원주방향의 수소화물이 존재하는 경우에는 연성이 심각하 게 저하되지 않고 $[58,90]$ 수소화물 재배열과 관련된 인자 가 증가할수록 DBTT는 증가하는 경향을 보여준다 $[57,87$, 91, 92]. 따라서 사용후핵 연료의 DBTT를 정량적으로 결정 하기 위해서는 다양한 수소농도에서 반경 방향과 원주방 향의 비율에 따른 각각의 지르코늄합금 (Zircaloy-4, Zirlo, HANA)에 대한 실험자료와 수소화물재배열에 대한 분석 이 필수적이다.

\section{5. 사용후핵연료 규제요건}

사용후핵연료의 장기 저장에 관한 연구와 함께 28 년 이상의 저장 경험을 갖고 있는 미국 $\mathrm{NRC}$ 는 과거 크립에 의한 변형과 크립파단을 사용후핵연료 피복관의 건전성 을 위협하는 주요 열화기구로 인식하였다. 이러한 이유 로 NRC는 건식저장 기간 중 확산지배공동성장(Diffusion controlled Cavity Growth, DCCG) 모델에 기반해 핵연 료 피복관 온도 제한을 설정하였으며[93], 이후 연소도 45 $\mathrm{GWd} / \mathrm{tU}$ 를 고연소와 저연소 핵연료의 구분 기준점으로 하고 실질적인 사용후핵연료의 크립 자료[52]를 바탕으로 $1 \%$ 변형률로 제한하는 방법을 받아들였다 [21]. 그러나 개
정된 Interim Staff Guidance(ISG)-11, Rev.2 [94]에서는 피복관의 첨두 온도가 $400^{\circ} \mathrm{C}$ 이하로 유지되는 경우 크립으 로 인한 심각한 변형이 발생하지 않는다는 잠정적인 결론 을 내리고 정상상태 및 짭은 비정상상태에서 피복관의 온 도를 $400^{\circ} \mathrm{C}$ 이하로 유지하고 수소화물재배열을 고려하여 사용후핵연료 피복관의 열주기 횟수를 최소화하고 열주기 로 인한 온도변화 범위를 $65^{\circ} \mathrm{C}$ 이하로 유지할 것을 권고하 였다. 그러나 개정된 ISG-11, Rev. 3[25]에서는 저연소 연 료의 경우 크립이 발생할 확률이 낮다고 판단하여 수소화 물 재배열만을 고려한 $400^{\circ} \mathrm{C}$ 의 온도 제한이 아닌 $90 \mathrm{MPa}$ 의 원주응력을 제한 기준으로 제시하였고 이 기준이 현재 규제요건으로 사용되고 있다[26].

일본의 경우 원자력안전기구(Japan Nuclear Energy Safety Organization, JNES)를 중심으로 사용후핵연료의 인허가를 위한 고유 저장기준 설정을 위한 시험을 수행하 였다[10]. JNES는 수소화물재배열과 수소취성을 피복관 건 전성에 가장 큰 영향을 미치는 열화기구로 규정하고 피복 관 재질에 따라 피복관의 연성저하가 나타나지 않는 세부 적인 조건을 설정하였다[27](Table 1). 규제요건을 살펴보 면 크게 연소도에 따라 연료를 구분하였고 $\mathrm{NRC}$ 기준보다 낮은 응력과 온도로 저장조건을 제한하고 있다. $48 \mathrm{GWd}$ $\mathrm{tU}$ 의 Zircaloy- 4 의 경우 피복관의 첨두 온도는 $275^{\circ} \mathrm{C}$ 이 하, 원주응력은 $100 \mathrm{MPa}$ 이하를 유지할 것을 명시하고 있 다. 이 기준은 수소화물재배열과 DBTT를 고려한 것으로 $\left(275^{\circ} \mathrm{C}\right.$ 에서 수소화물의 고용도는 약 $\left.55 \mathrm{wppm}\right)$ 수소화 물재배열이 발생한다 하더라도 그 양이 작아서 피복관의 건전성을 유지할 수 있기 때문이다. 저장관점에서 본다면 $\mathrm{NRC}$ 기준보다 JNES의 기준이 더 자세하고 저장온도가 더 
낮은 관계로 추가적인 냉각이 필요할 것으로 예상된다. 한 편 건식저장을 수행하고 있는 독일, 스페인 등은 $1 \%$ 크 립 변형률과 각각 $370^{\circ} \mathrm{C}$ 와 $400^{\circ} \mathrm{C}$ 의 저장기준을 갖고 있 다[95].

건식저장 운영초기 사용후핵연료의 특성에 대한 연구 는 미국과 독일의 주도아래 1970년대 중반부터 1980년대 초반까지 그 당시 주요 피복관 재질이었던 Zircaloy-2와 Zircaloy- 4 를 대상으로 활발하게 이루어졌다. 그때까지의 연료는 대개 $45 \mathrm{GWd} / \mathrm{tU}$ 이하의 저연소 연료였으며 미국 은 유카마운틴 처분장이 개시되기 전까지인 20 년 만 운 영할 계획이었다. 그러나 처분장 운영이 연기됨에 따라 추 가적인 40 년 인허가 연장을 허용하였고 최근 처분장 계 획이 전면 취소됨에 따라 200 년 이상의 장기 건식저장에 대한 논의가 제기되고 있다. 그러나 약 28 년이 경과한 지 금, M5, ZIRLO, MDA, HANA 등 다양한 피복관이 개발되 었으며, 고연소도 운전과 함께 $45 \mathrm{GWd} / \mathrm{tU}$ 이상의 고연소 된 사용후핵연료가 방출되고 있는 실정이다. 한편 국내에 서도 가까운 미래에 Zircaloy-4, Zirlo 사용후핵연료와 함 께 HANA 피복관도 방출될 것이다. 미국과 일본의 사례에 서 알 수 있듯이 고연소도 사용후핵연료와 함께 다양한 피 복관 재질에 대한 건전성 연구 역시 반드시 필요하다. 비 록 신합금 피복관의 경우 기계적 강도가 우수하고 산화 저 항성이 향상되는 등의 장점을 갖고 있지만 건식저장 상황 에서의 재료적 특성과 수송상황에서의 기계적 물성 등에 대한 값은 아직 검증되지 않았기 때문이다.

\section{6. 결론}

본 연구에서는 건식저장 상황에서 사용후핵연료의 특 성 및 건전성에 대하여 현재까지 보고되고 논의된 사항들 을 면밀히 재검토하고 향후 추구해야 할 연구방향을 제시 하고자 하였다. 본 연구 결과를 요약 정리하면 아래와 같 다.

· 국내 사용후핵연료의 평균 방출연소도는 이미 45 $\mathrm{GWd} / \mathrm{tU}$ 를 초과하였고 방출연소도는 꾸준히 증가하 는 추세이다. 이처럼 국내에서도 고연소도를 가진 사 용후핵연료의 양이 증가하고 있다는 사실은 연소도가 높을수록 연소이력에 따른 사용후핵연료의 건식 저장 초기 재료적 조건이 열악해진다는 최근의 연구 결과를
상기할 때 앞으로 진행될 국내 사용후핵연료 건식 저 장 연구 개발의 방향을 새롭게 정립해야 할 필요성이 제기되고 있다.

· 2000년대 초까지 피복관의 크립 변형이 장기 건식저 장 시 가장 중요한 사용후핵연료 피복관의 열화기구로 알려졌었으나, 최근 연구 결과 수소화물에 의한 영향이 사용후핵연료의 건전성에 가장 큰 위협을 줄 수 있는 것으로 밝혀지고 있으며, 이들에 의한 주요 열화 기구 로는 수소화물재배열과 지연수소화균열 등이 있고 수 소화물로 인한 연성-취성 천이 또한 고려해야 할 대상 으로 파악되고 있다.

- 한편 수소화물 재배열이 발생하는 문턱응력으로 90 $\mathrm{MPa}$ 이 제시되어 저장기준으로 사용되고 있지만 최근 연구에 따르면 $90 \mathrm{MPa}$ 이하의 응력에서도 재배열이 발 생되고 문턱응력 또한 온도에 따라 변화한다고 보고되 고 있다. 최근 국내에서 수행된 연구 결과는 저연소 국 내 사용후핵 연료(방출연소도 $45 \mathrm{GWd} / \mathrm{tU}$ 이하)의 경우 피복관에 걸리는 응력이 $90 \mathrm{MPa}$ 이하일 것으로 예측되 지만 고연소도 영역에서는 $90 \mathrm{MPa}$ 을 초과하는 연료도 충분히 존재할 수 있다고 보고하고 있다. 그러므로 국 내에서도 명확한 사용후핵연료의 건전성 평가를 위해 수소화물에 대한 좀 더 세밀한 연구가 필요하다. 아울 러 새로운 피복관 재질의 사용후핵연료에 대한 연구범 위 확대도 동반되어야 한다.

- 미국은 단일한 저장온도 $\left(400^{\circ} \mathrm{C}\right)$ 기준과 저연소도 사용후핵연료에 대한 비교적 관대한 규제기준을 $(90$ $\mathrm{MPa}$ ) 적용하고 있는 반면, 일본은 최근 10 년의 연구결 과를 바탕으로 구체적이고 보수적인 규제기준을 제시 하였다. 일본의 경우, 특정한 단일의 열화기구 생성을 억제하기 위한 기준이 아니라, 피복관이 전체적으로 재 료적인 열화를 겪지 않을 기준을 제시하였다. 그러나, 현재까지 많은 나라에서 $1 \%$ 이하의 크립 변형률을 공 식적인 사용후핵연료 피복관 규제기준으로 채택하고 있는 상황이다.

- 따라서 국내 고유의 규제 기준을 수립하기 위해서는 사용후핵연료 피복관 열화에 대한 충분한 실험자료를 생산하여야 한다. 공통적인 규제기준으로 사용되고 있 는 크립 실험을 비롯하여 수소화물 재배열, 온도에 따 른 피복관 인장·압축 실험, 파괴인성, 지연수소화균열 실험 등의 사용후핵연료 열화와 관련된 광범위한 기초 실험이 필수적이다. 
이상에서 살펴본 바와 같이, 국내 사용후핵연료에 대 한 충분한 자료 생산 및 분석이 우선되어야 하며, 건식저 장 환경에서 사용후핵연료의 거동에 대한 연구를 지속적 으로 수행하는 것이 필요하다. 이러한 연구결과는 국내 고 유 저장시스템의 설계 및 규제기준 정립에 기여할 수 있으 며, 나아가 사용후핵연료 건식저장에 대한 대국민 수용성 증진에도 크게 기여할 것이다.

\section{감사의 글}

본 연구는 산업통상자원부 방사성폐기물 관리기술개 발의 일환으로 수행되었으며, 이에 감사드립니다.

\section{REFERENCES}

[1] H.J. Choi, D. Cho, D. Kook, and J. Choi, "Current status of spent fuels and the development of computer programs for the PWR spent fuel management in Korea", Progress in Nuclear Energy, 53(3), pp. 290-297 (2011).

[2] Nuclear Safety and Security Commission (NSSC), Annual Report, p.180 (2012).

[3] M. A. McKinnon and V. A. DeLoach, "Spent nuclear fuel storage - Performance tests and demonstrations", Pacific Northwest Laboratory Report, PNL-8451 (1993).

[4] M. A. McKinnon and M. E. Cunningham, "Dry Storage Demonstration for High-Burnup Spent Nuclear Fuel-Feasibility Study", Pacific Northwest National Laboratory Report, PNNL-14390 (2003).

[5] H. Tsai and M. C. Billone, "Thermal Creep of Irradiated Zircaloy Cladding", ASTM special technical publication, 1467, pp. 632-650 (2006).

[6] R. E. Einziger, S. D. Atkin, V. Pasupathi, and D. E. Stellrecht, "High temperature postirradiation materials performance of spent pressurized water reactor fuel rods under dry storage conditions", Nucl. Technol., 57(1), pp. 65-80 (1982).

[7] W. Goll, H. Spilker, and E. H. Toscano, "Short-time creep and rupture tests on high burnup fuel rod cladding", Journal of nuclear materials, 289(3), pp. 247-
253 (2001).

[8] H. M. Chung, R. S. Daum, J. M. Hiller, and M. C. Billone, "Charateristics of Hydride Precipitation and Reorientation in Spent-Fuel Cladding", ASTM special technical publication, 1423, pp. 561-582 (2002).

[9] H. C. Chu, S. K. Wu, and R. C. Kuo, "Hydride reorientation in Zircaloy-4 cladding", Journal of nuclear materials, 373(1-3), pp. 319-327 (2008).

[10] M. Aomi, T. Baba, T. Miyashita, K. Kamimura, T. Yasuda, Y. Shinohara, and T. Takeda, "Evaluation of Hydride Reorientation Behavior and Mechanical Properties for High-Burnup Fuel-Cladding Tubes in Interim Dry Storage", ASTM special technical publication, 1505, pp. 651-673 (2009).

[11] R. Dutton, K. Nuttall, M. P. Puls, and L. A. Simpson, "Mechanisms of hydrogen induced delayed cracking in hydride forming materials", Metallurgical Transactions A, 8, pp. 1553-1562 (1977).

[12] Y. S. Kim, "Delayed hydride cracking of spent fuel rods in dry storage", Journal of nuclear materials, 378(1), pp. 30-34 (2008).

[13] M. P. Puls, "Review of the thermodynamic basis for models of delayed hydride cracking rate in zirconium alloys", Journal of nuclear materials, 393(2), pp. 350-367 (2009).

[14] K. Une, "Influences of cesium and cesium oxide on iodine stress corrosion cracking of Zircaloy-2 in out-of-pile and in-pile conditions", Journal of nuclear materials, 87(1), pp. 207-210 (1979).

[15] A. Tassoji, R. E. Einziger, and A. K. Miller, "Modeling of Zircaloy Stress-Corrosion Cracking: Texture Effects and Dry storage Spent Fuel Behavior", ASTM special technical publication, 824, pp. 595626 (1984).

[16] M. A. McKinnon, R. E. Einziger, D. L. Baldwin, and S. G. Pitman, "Data Needs for Long-Term Dry Storage of LWR Fuel", Electric Power Research Institute Report, EPRI-TR-108757 (1998).

[17] L. D. Blackburn, D. G. Farwick, S. R. Fields, L. A. James, and R. A. Moen, "Maximum Allowable 
Juseong Kim. et al : Review on Spent Nuclear Fuel Performance and Degradation Mechanisms under Long-term Dry Storage

Temeprature For Storage of Spent Nuclear Reactor Fuel", Handford Engineering Develoment Laboratory Report, HEDL-TME 78-37 (1978).

[18] M. Peehs, F. Garzarolli, and W. Goll, "Assessment of Dry Storage Performance of Spent LWR Fuel Assemblies with Increasing Burnup", IAEASM-352-39, pp. 313-324 (1984).

[19] M. Peehs and J. Fleisch, "LWR Spent Fuel Storage Behaviour", Journal of nuclear materials, 137(3), pp. 190-202 (1986).

[20] B. A. Chin, M. A. Khan, and J. C. L. Tarn, "Deformation and Fracture Map Methdology for Predicting Cladding Behavior during Dry Storage", Pacific Northwest Laboratory Report, PNL-5998 (1986).

[21] US NRC Spent Fuel Project Office, "Interim Staff Guidance-11, Revision 1" (2000).

[22] D. H. Kook, J. W. Choi, J. S. Kim, and Y. S. Kim, "Review of Spent Fuel Integrity Evaluation For Dry Storage", Nuclear Engineering and Technology, 45(1), pp. 115-124 (2013).

[23] J. Kessler and R. E. Einziger, "Technical Bases for Extended Dry Storage of Spent Nuclear Fuel", Electric Power Research Institute Report, EPRI1003416 (2002).

[24] B. Hanson, H. Alsaed, C. Stockman, D. Enos, R. Meyer, and K. Sorenson, "Gap Analysis to Support Extended Storage of Used Nuclear Fuel Rev.0", Pacific Northwest National Laboratory Report, PNNL20509, p. 198 (2012).

[25] US NRC Spent Fuel Project Office, "Interim Staff Guidance-11, Revision 3" (2003).

[26] U.S. Nuclear Regulatory Commission (NRC), "Standard review plan for dry cask storage systems", Nuclear Regulatory Commission Report, NUREG-1536, revision 1 (2010).

[27] K. Kamimura, "Integrity criteria of spent fuel for dry storage in Japan", International Seminar on Spent Fuel Storage (ISSF), Tokyo, Japan (2010).

[28] EPRI, "Spent Fuel Transportation Applications: Longitudinal Tearing Resulting from Transportation Accidents-A Probabilistic Treatment", Electric
Power Research Institute Report, EPRI-1013448 (2006).

[29] J. S. Kim, H. K. Yoon, D. H. Kook, and Y. S. Kim, "A Study on the Initial Characteristics of Domestic Spent Nuclear Fuels for Long Term Dry Storage", Nuclear Engineering and Technology, 45, pp. 337384 (2013).

[30] S.J. Kim, K. Ho Kim, J. Hyuk Baek, B. Kwon Choi, Y. Hwan Jeong, and Y. Ho Jung, "The effect of hydride on the corrosion of Zircaloy-4 in aqueous $\mathrm{LiOH}$ solution", Journal of nuclear materials, 256(1-3), pp. 114-123 (1998).

[31] S. Müller and L. Lanzani, "Corrosion of zirconium alloys in concentrated lithium hydroxide solutions", Journal of nuclear materials, 439, pp. 251-257 (2013).

[32] Y.S. Kim, Y.H. Jeong, and S.B. Son, "A study on the effects of dissolved hydrogen on zirconium alloys corrosion", Journal of nuclear materials, 444(13), pp. 349-355 (2014).

[33] M. P. Short, D. Hussey, B. K. Kendrick, T. M. Besmann, C. R. Stanek, and S. Yip, "Multiphysics modeling of porous CRUD deposits in nuclear reactors", Journal of nuclear materials, 443(1-3), pp. 579-587 (2013).

[34] G. A. Berna, C. E. Beyer, K. L. Davis, and D. D. Lanning, "FRAPCON-3: A Computer Code for the Calculation of Steady-state, Thermal-Mechanical Behavior of Oxide Fuel Rods for High Burnup", NUREG/CR-6534, PNNL-11513 (1997).

[35] B. G. Kammenzind, D. G. Franklin, H. R. Peters, and W. J. Duffin, "Hydrogen Pickup and Redistribution in Alpha-Annealed Zircaloy-4", ASTM special technical publication, 1295, pp. 338-369 (1996).

[36] R. E. Einziger, H. C. Tsai, M. C. Billone, and B. A. Hilton, Examination of Spent PWR Fuel Rods After 15 Years in Dry Storage (2002).

[37] H. Tsai and M. C. Billone, "Characterization of High-Burnup PWR and BWR Rods", Nuclear Safety Research Conference, October 28-30, 2002, Washington D.C., 2002. 
[38] W. Wiesenack, "Review of Halden reactor project high burnup fuel data that can be used in safety analyses", Nuclear Engineering and Design, 172, pp. 83-92 (1997).

[39] K. J. Geelhood, W. G. Luscher, and C. E. Beyer, "FRAPCON-3.4: A Computer Code for the Calculation of Steady-State Thermal-Mechanical behavior of Oxide Fuel Rods for High Burnup", NUREG/ CR-7022, PNNL-19418, 1 (2011).

[40] S. M. Bowman and L. C. Leal, "ORIGEN-ARP: Automatic Rapid Process for Spent Fuel Depletion, Decay, and Source Term Analysis", NUREG/CR0200, Revision 6, 1 (2000).

[41] Y. Rashid and R. Dunham, "Creep Modeling and Analysis Methodlology for Spent Fuel in Dry Storage", Electric Power Research Institute Report, EPRI-1003135 (2001).

[42] R. E. Einziger, H. Tsai, M. C. Billone, and B. A. Hilton, "Examination of Spent PWR Fuel Rods after 15 Years in Dry Storage", Argonne National Laboratory Report, ANL-03/17 (2003).

[43] C. W. Enderlin, D. R. Rector, J. M. Cuta, R. E. Dodge, and T. E. Michener, "COBRA-SFS: A thermal-hydraulic analysis code for spent fuel storage and transportation casks", Pacific Northwest National Laboratory Report, PNL-10782 (1995).

[44] X. Heng, G. Zuying, and Z. Zhiwei, "A numerical investigation of natural convection heat transfer in horizontal spent-fuel storage cask", Nuclear Engineering and Design, 213, pp. 59-65 (2002).

[45] R. A. Brewster, E. Baglietto, E. Volpenhein, and C. S. Bajwa, "CFD Analyses of the TN-24P PWR Spent Fuel Storage Cask", ASME 2012 Pressure Vessels and Piping Conference, 3, pp. 17-25 (2012).

[46] J. C. Lee, W. S. Choi, K. S. Bang, K. S. Seo, and S. Y. Yoo, "Thermal-fluid flow analysis and demonstration test of a spent fuel storage system", Nuclear Engineering and Design, 239(3), pp. 551-558 (2009).

[47] R. Lo Frano, G. Pugliese, and G. Forasassi, "Thermal analysis of a spent fuel cask in different trans- port conditions", Energy, 36(4), pp. 2285-2293 (2011).

[48] S. H. Yoo, H. C. No, H. M. Kim, and E. H. Lee, "CFD-assisted scaling methodology and thermalhydraulic experiment for a single spent fuel assembly", Nuclear Engineering and Design, 240(12), pp. 4008-4020 (2010).

[49] S. H. Yoo, H. C. No, H. M. Kim, and E. H. Lee, "Full-scope simulation of a dry storage cask using computational fluid dynamics", Nuclear Engineering and Design, 240, pp. 4111-4122 (2010).

[50] K. Kamimura, N. Kohno, K. Itoh, Y. Tsukuda, T. Yasuda, M. Aomi, K. Murai, H. Fujii, and Y. Senda, "Thermal creep tests of BWR and PWR spent fuel cladding", IAEA-CN-102/27, pp. 375-385 (2003).

[51] R. E. Einsiger and R. Kohli, "Low-temperature rupture behavior of Zircaloy-clad pressurized water reactor spent fuel rods under dry storage conditions", Nucl. Technol., 67(1), pp. 107-123 (1984).

[52] H. Spilker, M. Peehs, H.P. Dyck, G. Kaspar, and K. Nissen, "Spent LWR fuel dry storage in large transport and storage casks after extended burnup", Journal of nuclear materials, 250(1), pp. 63-74 (1997).

[53] K. Ito, K. Kamimura, and Y. Tsukuda, "Evaluation of Irradiation Effect on Spent Fuel Cladding Creep Properties", Proceedings of the 2004 International meeting on LWR fuel performance, pp. 440-451 (2004).

[54] Y. R. Rashid, D. J. Sunderland, and R. O. Montgomery, "Creep as the Limiting Mechanism for Spent Fuel Dry Storage", Electric Power Research Institute Report, EPRI-1001207 (2000).

[55] R. N. Singh, R. Kishore, S. S. Singh, T. K. Sinha, and B. P. Kashyap, "Stress-reorientation of hydrides and hydride embrittlement of $\mathrm{Zr}-2.5 \mathrm{wt} \% \mathrm{Nb}$ pressure tube alloy", Journal of nuclear materials, 325(1), pp. 26-33 (2004).

[56] S. I. Hong and K. W. Lee, "Stress-induced reorientation of hydrides and mechanical properties of Zircaloy-4 cladding tubes", Journal of nuclear mate- 
Juseong Kim. et al : Review on Spent Nuclear Fuel Performance and Degradation Mechanisms under Long-term Dry Storage

rials, 340, pp. 203-208 (2005).

[57] M. C. Billone, T. A. Burtseva, and R. E. Einziger, "Ductile-to-brittle transition temperature for highburnup cladding alloys exposed to simulated dryingstorage conditions", Journal of nuclear materials, 433(1-3), pp. 431-448 (2013).

[58] H. C. Chu, S. K. Wu, K. F. Chien, and R. C. Kuo, "Effect of radial hydrides on the axial and hoop mechanical properties of Zircaloy-4 cladding", Journal of nuclear materials, 362, pp. 93-103 (2007).

[59] K. Kese, "Hydride re-orientation in zircaloy and its effect on the tensile properties", Swedish Nuclear Power Inspectorate, (SKI) Report 98:32 (1998).

[60] H. M. Chung, "Understanding Hydride- and Hydrogen-related Processes in High-burnup Cladding in Spent-fuel Storage and Accident Situations", Proceedings of the 2004 International meeting on LWR fuel performance, pp. 470-479 (2004).

[61] C. Cappelaere, R. Limon, D. Gilbon, T. Bredel, O. Rabouille, P. Bouffioux, and J. P. Mardon, "Impact of Irradiation Defects Annealing on Long-Term Thermal Creep of Irradiated Zircaloy-4 Cladding Tube", ASTM special technical publication, 1423, pp. $720-737$ (2002).

[62] R. S. Daum, S. Majumdar, Y. Liu, and M. C. Billone, "Radial-hydride Embrittlement of High-burnup Zircaloy-4 Fuel Cladding", Journal of nuclear science and technology, 43(9), pp. 1054-1067 (2006).

[63] T. Oohama, M. Okunishi, Y. Senda, K. Murakami, and M. Sugano, "Study on Hydride Re-Orientation Properties in Zircaloy-4 Cladding Tube", Nuclear reactor thermal hydraulics, operations and safety, 2004, p. N6P117 (2004).

[64] S. Valance, J. Bertsch, and A. M. Alam, "Statistical Analysis of Hydride Reorientation Properties in Irradiated Zircaloy-2", ASTM special technical publication, 1529, pp. 523-543 (2011).

[65] K. Sakamoto and M. Nakatsuka, "Stress Reorientation of Hydrides in Recrystallized Zircaloy-2 Sheet", Journal of nuclear science and technology, 43(9), pp. 1136-1141 (2006).
[66] Y. Mishima, T. Okubo, and E. Sano, "Effect of thermal cycling on the stress orientation of hydride in zircaloy", Metallurgical Transactions, 2(7), pp. 1995-1997 (1971).

[67] M. P. Puls, "The effects of misfit and external stresses on terminal solid solubility in hydride-forming metals", Acta Metallurgica, 29(12), pp. 1961-1968 (1981).

[68] P. Vizcaíno, A. Banchik, and J. Abriata, "Hydrogen in Zircaloy-4: effects of the neutron irradiation on the hydride formation", Journal of Materials Science, 42(16), pp. 6633-6637 (2007).

[69] Z. L. Pan and M. P. Puls, "Precipitation and dissolution peaks of hydride in $\mathrm{Zr}-2.5 \mathrm{Nb}$ during quasistatic thermal cycles", Journal of Alloys and Compounds, 310(1-2), pp. 214-218 (2000).

[70] R. N. Singh, S. Mukherjee, A. Gupta, and S. Banerjee, "Terminal solid solubility of hydrogen in $\mathrm{Zr}$ alloy pressure tube materials", Journal of Alloys and Compounds, 389(1-2), pp. 102-112 (2005).

[71] B. F. Kammenzind, B. M. Berquist, R. Bajaj, P. H. Kreyns, and D. G. Franklin, "The Long-Range Migration of Hydrogen Through Zircaloy in Response to Tensile and Compressive Stress Gradients", ASTM special technical publication 1354, pp. 196232 (2000).

[72] C. J. Simpson and C. E. Ells, "Delayed hydrogen embrittlement in Zr-2.5wt \% Nb", Journal of nuclear materials, 52(2), pp. 289-295 (1974).

[73] IAEA, "Delayed hydride cracking in zirconium alloys in pressure tube nuclear reactors", International Atomic Energy Agengy Report, IAEA-TECDOC-1410 (2004).

[74] F. R. Ambler, "Effect of Direction of Approach to Temperature on the Delayed Hydrogen Cracking Behabior of Cold-Worked Zr-2.5Nb", ASTM special technical publication, 824, pp. 653-674 (1984).

[75] M. P. Puls, "On the consequences of hydrogen supersaturation effects in $\mathrm{Zr}$ alloys to hydrogen ingress and delayed hydride cracking", Journal of nuclear materials, 165(2), pp. 128-141 (1989). 
[76] S. Q. Shi, G. K. Shek, and M. P. Puls, "Hydrogen concentration limit and critical temperatures for delayed hydride cracking in zirconium alloys", Journal of nuclear materials, 218(2), pp. 189-201 (1995).

[77] Y. S. Kim, "Author's reply to "Review of the thermodynamic basis for models of delayed hydride cracking rate in zirconium alloys, M.P. Puls in J. Nucl. Mater. 393 (2009) 350-367", Journal of nuclear materials, 399(2-3), pp. 240-247 (2010).

[78] Y. S. Kim, "Author's 2nd reply to comments on author's reply to "Review of the thermodynamic basis for models of delayed hydride cracking rate in zirconium alloys", M.P. Puls in J. Nucl. Mater. 393 (2009) 350-367", Journal of nuclear materials, 399(2-3), pp. 259-265 (2010).

[79] F. Yunchang and D. A. Koss, "The influence of multiaxial states of stress on the hydrogen embrittlement of zirconium alloy sheet", Metallurgical Transactions A, 16(4), pp. 675-681 (1985).

[80] G. W. Parry and W. Evans, "Occurrence of ductile hydrides in zircaloy-2", Nucleonics, 22, p. 117 (1964).

[81] W. M. Mueller, J. P. Blackledge, G. G. Libowitz, and U. S. A. E. Commission, Metal hydrides: Academic Press (1968).

[82] L. A. Simpson and C. D. Cann, "Fracture toughness of zirconium hydride and its influence on the crack resistance of zirconium alloys", Journal of nuclear materials, 87, pp. 303-316 (1979).

[83] M. C. Billone and Y. Liu, "Perspectives on DBTT for High-Burnup Fuel Cladding", ESCP Meeting, St. Petersburg, FL, May 6 (2013).

[84] S. R. Reid and T. Y. Reddy, "Effect of strain hardening on the lateral compression of tubes between rigid plates", International Journal of Solids and Structures, 14(3), pp. 213-225 (1978).

[85] M. Nemat-Alla, "Reproducing hoop stress-strain behavior for tubular material using lateral compression test", International Journal of Mechanical Sciences, 45(4), pp. 605-621 (2003).

[86] L. G. Bell and R. G. Duncan, "Hydride reorientation in $\mathrm{Zr}-2.5 \% \mathrm{Nb}$; How it is Affected by Stress, Temperature and Heat Treatment", Atomic Energy of Canada Limited Report, AECL-5110 (1975).

[87] A. C. Wallace, G. K. Shek, and O. E. Lepik, "Effects of Hydride Morphology on $\mathrm{Zr}-2.5 \mathrm{Nb}$ Fracture Toughness", ASTM special technical publication, 1023, pp. 66-88 (1989).

[88] ASTM B811-02, "Standard Specification for Wrought Zirconium Alloy Seamless Tubes for Nuclear Reactor Fuel Cladding" (2007).

[89] P. A. Raynaud, D. A. Koss, and A. T. Motta, "Crack growth in the through-thickness direction of hydrided thin-wall Zircaloy sheet", Journal of nuclear materials, 420(1-3), pp. 69-82 (2012).

[90] S. K. Yagnik, R. C. Kuo, Y. R. Rashid, A. J. Machiels, and R. L. Yang, "Effect of Hydrides on the Mechanical Properties of Zircaloy-4", Proceedings of the 2004 International meeting on LWR fuel performance, pp. 191-199 (2004).

[91] L. A. Simpson and C. K. Chow, "Effect of Metallurgical Variables and Temperature on the Fracture Toughness of Zirconium Alloy Pressure Tube", ASTM special technical publication, 939, pp. 579596 (1987).

[92] P. H. Davies and C. P. Stearns, "Fracture toughness testing of Zircaloy-2 pressure tube material with radial hydrides using direct-current potential drop", ASTM special technical publication, 905, pp. 379400 (1986).

[93] U.S. Nuclear Regulatory Commission (NRC), "Standard Review Plan for Dry Cask Storage Systems", Nuclear Regulatory Commission Report, NUREG-1536 (1997).

[94] US NRC Spent Fuel Project Office, "Interim Staff Guidance-11, Revision 2" (2002).

[95] H. G. Kim, Y. H. Jeong, and K. T. Kim, "The Effects of Creep and Hydride on Spent Fuel Integrity during Interim Dry Storage", Nuclear Engineering and Technology, 42(3), pp. 249-258 (2010). 